\title{
Jeolojik Miras Nitelikli Türkiye Doğal Taşları
}

\author{
Natural Stones Qualified as Geological Heritage in Turkey
}

\author{
Nizamettin KAZANCI ${ }^{1,3}$, Alper GÜRBÜZZ ${ }^{2,3}$ \\ ${ }^{1}$ Ankara Üniversitesi, Mühendislik Fakültesi, Jeoloji Mühendisliği. Bölümü, 06100 Tandoğan, Ankara \\ ${ }^{2}$ Niğde Üniversitesi, Mühendislik Fakültesi, Jeoloji Mühendisliği Bölümü,51240, Niğde \\ ${ }^{3}$ Jemirko-Jeolojik Mirast Koruma Derneği, P.K. 10, 06100 Maltepe, Ankara, \\ (E-Posta:nkazanci@ankara.edu.tr)
}

\section{ÖZ}

Türkiye jeolojik yapısından dolayı doğal taşların çok çeşitli ve göreceli bol olduğu bir ülkedir. Kendine özgü çok sayıda doğal taş antik dönemlerden bu yana kullanılmaktadır. Bunların birçoğu jeolojik miras niteliğindedir ve fakat henüz tespitleri yapılmamıştır. Ayrıca, ticari ve bilimsel anlamda doğal taş terminolojisi farklı olduğu gibi, doğal taşlar hakkındaki jeolojik bilgiler de sınırlıdır. Konuya yerbilimcilerin dikkatini çekmek amacıyla, bu yazıda doğal taşların kültürel jeolojideki yeri (veya doğal taş kültürünün jeolojik temelleri) tartışılmış-ve eşsiz yapı malzemeleri olan Ahlat Taşı, Ankara Taşı, Nevşehir Taşı, Sille Taşı ile özgün el işçiliği hammaddeleri olan Lületaşı, Pileki Taşı ve Oltu Taşı hakkında özet bilgiler verilmiştir.

Anahtar kelimeler: Ahlat Taşı, Doğal taşlar, Jeomiras taşlar, Kültürel jeoloji, Lületaşı

\section{ABSTRACT}

Natural stones qualified as geological heritage are various and also plenty in Turkey, based on its complex geological framework. Some unique stones have been used in Anatolia since antic times, particularly for large and prestigious buildings. Most of the natural stones are typical geoheritages of the country. However they have been no documented at international level, yet. In addition, economic and scientific terminology on the Turkish natural stones are completely different and people do not have correct geological knowledge about them. In this study, to be able to take attention of earth scientists to the subject, the roles of natural stones in cultural geology (or the geological fundamentals of natural stone culture) have been discussed providing brief information about the unique building materials Ahlat Stone, Ankara Stone, Nevşehir Stone Sille Stone and Lületaşı (meerschaum), Pileki Stone, Oltu Stone as raw materials for local handcrafts.

Keywords: Ahlat Stone, Cultural geology, Geoheritage stones, Lületaşı (meerschaum), Natural Stones 


\section{GíRiş}

Yerbilimlerinin bilgi kaynağı olan doğal taşlar, yaşamın değilse bile dünyadaki gelişmelerin ve kültürün temeli olmuştur. Bunu anlamak için, örneğin ilk insanların el baltalarını, yerleşim mağaralarını, Göbekli Tepe'yi, Mısır piramitlerini, Efes harabelerini, Ayasofya'yı, Selimiye Cami'ini, Anıtkabir'i, Kaşıkçı elmasını veya müzelerdeki antik zaman taşlarını görmek yetecektir. Doğal taş denildiğinde çoğunlukla akla gelen yapı taşlarıdır, çünkü insanlık tarihinin en önemli eserleri taştan inşa edilmiştir. Eski veya yeni, bütün taş yapıların ortak özelliği, görkemli ve kalıcı oluşlarıdır. Bu yüzden taş kullanımı her kültürde her zaman tercih edilmiştir (Farrelly, 2011; DYDTS, 2012). Günümüzde de doğal taşların kullanımı sürmektedir. $\mathrm{Bu}$ kullanım tercihi bazı doğal taşların ününü artırmakta, yenilerinin piyasaya çıkmasını sağlamakta, bulunduğu yöre ve ülke için giderek büyüyen ekonomik değer oluşturmaktadır. Bununla birlikte, doğal kaynaklar ve yapı taşları sonsuz değildir. Rezervleri tükenebilir, hatta çevre şartlarından etkilenebilir ve bozulurlar (Gökaltun, 2004; 2011). Silip süpürmeye varan vahşi tüketimin çok yönlü sorunlar getirdiği yaşanarak öğrenilmiştir. Dolayısıyla sürdürülebilirlik esas olmalıdır, bu da "planlı kullanım" ile mümkündür. Bunun için doğal taş üretiminde köken, rezerv, alan dağılımı, gelecek öngörüsü, yöre ekonomisi, korunma ihtiyacı, çevre sorunları, verimlilik vb bütün yönlerin ortaya konulması ve bunlara taraf olan bütün ilgililerin hazırlanacak kullanım planlarında anlaşmaları gerekir. Dar alanlı planlar için bile yalnızca oradaki kaynaklar değil, tüm ülkede benzeri nelerin bulunduğu biliniyor olmalıdır. Çok sayıda işletme ve taş ocağı varlığına karşın, doğal yapı taşları ülkemizde yeterince biliniyor değildir. Mevcut bilgilerin büyük kısmı işletmecilerin internet sayfaları, çok az kısmı ise kullanım planlarına katkısı olmayan ileri incelemelerdir. En sık rastlanan çalışma ya ticari taş türlerinin adları ve yerleri (örn. Mutlu, 2005), ya da bu kayaların yapı taşı olarak kullanılabilirlikleri üzerinedir. Buna karşın Türkiye'nin hemen her yöresinin jeoloji incelemesi yapılmıştır, kayaçları ve istifleri hakkında bilgi mevcuttur. Ancak bunlar doğal yapı taşları ile ilişkilendirilmemiştir. Bunun tersine durum ise ülkenin hemen yer yerindeki kayaların yap1 taşı olarak değerlendirilmesi üzerine incelemelerdir. Yeni hammadde kaynakları bulmak amacıyla, jeoloji haritalarına bakılarak bir yerler seçilmekte, buralardaki göreli sert kayaların mühendislik özellikleri (birim hacim ağırlığı, su emme, özgül ağırlık, görünen gözeneklilik, basınç mukavemeti, eğilme mukavemeti, sürtünme ile aşındırma kaybı, donma çözünme sınırları, ses geçirgenliği, doğal su içeriği, kaya sertliği) ortaya konulmaktadır. Elde edilen veriler TSE ölçüleri ile karşıllaştırılarak işletme ve kullanım konularında öneriler yapılmaktadır. Bunlar taşocağ1 işletmecilerine hizmet eden hazır bilgilerdir. Bu tarz yaklaşımda jeolojik koruma, jeomiras, jeoestetik, taşları tanıtma kaygısı yoktur. $\mathrm{Bu}$ yazının amacı taşların doğal ve kültürel miras niteliklerine dikkat çekmek ve ekonomik ve kültürel değeri ulusal boyuta ulaşmış bazı doğal taşlar hakkında (Ahlat Taşı, Ankara Taşı, Lületaşı, Midyat Taşı, Nevşehir Taşı, Oltu Taşı, Pileki taşı, Sille Taşı, traverten ve mermer) yaptığımız araştırmaların ön sonuçlarını sunmaktır. Hemen belirtilmelidir ki, ülkemizdeki jeomiras nitelikli ünlü doğal taşlar elbette bunlardan ibaret değildir. Yazıda, yalnızca Türkiye'nin değişik yörelerinden örnekler verilmeye çalışılmıştır (Şekil1). 


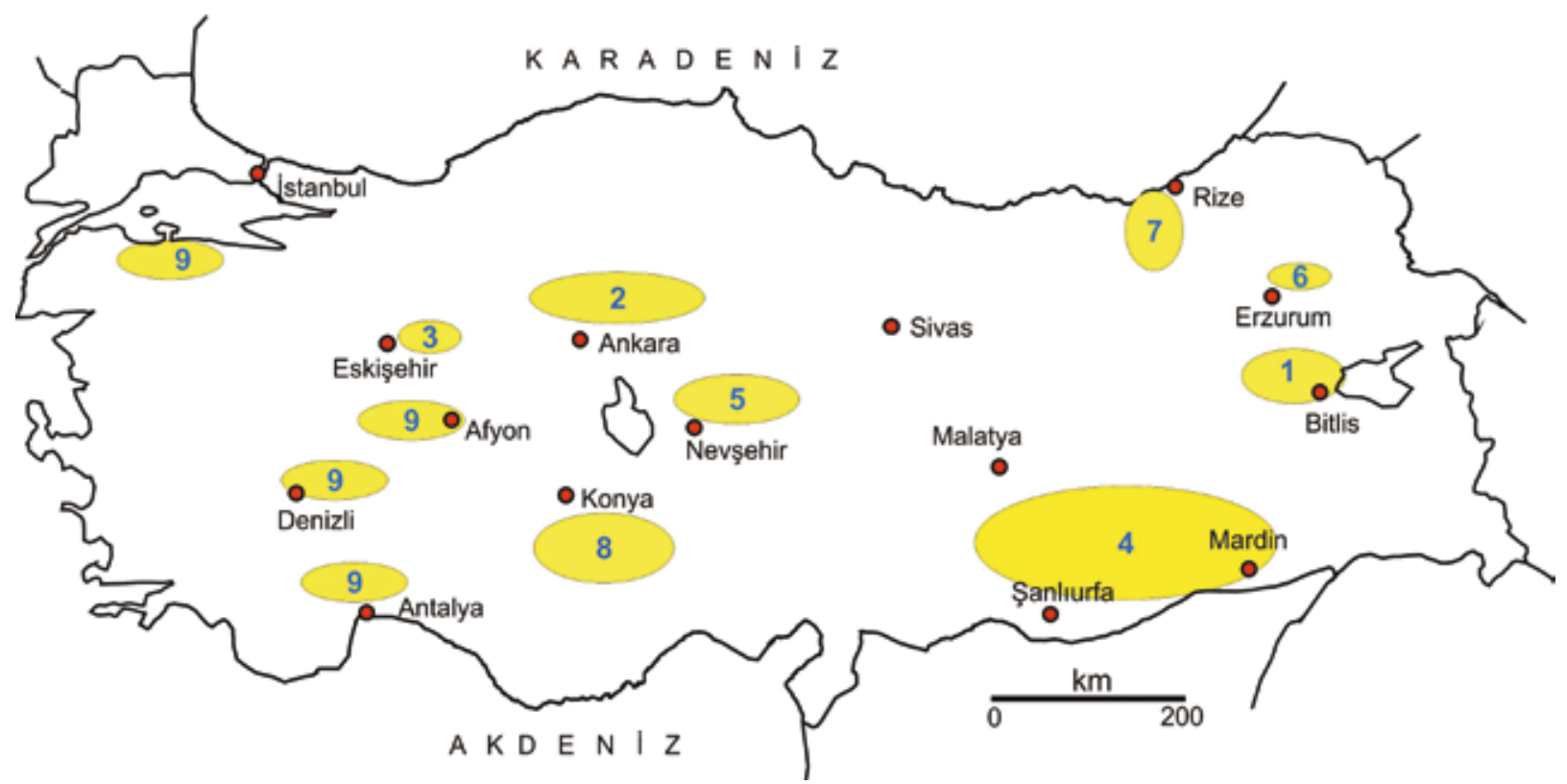

Şekil 1. Ülkemizdeki jeomiras nitelikli bir kısım doğal taşların yerleri; 1. Ahlat Taşı, 2. Ankara Taşı, 3. Lületaşı, 4. Midyat Taşı, 5. Nevşehir Taşı, 6. Oltu Taş1, 7. Pileki Taşı, 8. Sille Taşı, 9. Önemli traverten ve mermer yatakları. Boyalı alanların büyüklüğü göreceli rezerv karşılaştırması içindir.

Figure 1. Location of natural stones studied and qualified as geoheritages in Turkey; 1. Ahlat Stone, 2. Ankara Stone, 3. Meerschaum, 4. Midyat Stone, 5. Nevşehir Stone, 6. Oltu Stone, 7. Pileki Stone, 8. Sille Stone, 9. Significant travertines and marble beds. Symbols show the comparable reserves of the Stones.

Mimarlık ve sanat tarihi, aynı zamanda doğal taşların kullanım tarihidir (Farrelly, 2011). Bütün ünlü yapıların taşlarının nerelerden getirildiği belgelidir. Yapılara yenileme veya bakım gerektiğinde orijinal taş ocaklarının kullanılması önerilmektedir. Çünkü zaman içinde yap1 ünlenirken, onu görkemli kılan taşlar daha çok aranır olmakta, böylece eserler gibi orada kullanılan taşlar da "ulusal değer" halini almaktadır. Bu bir süreçtir ve yaşanmış olması şanstır. Bütün gelişmiş ülkeler böyle doğal taşları ve taş ocaklarını "doğal ve kültürel sit", genellikle de "jeolojik miras" olarak görmektedirler (örn. BGS, 2011; EGS, 2011; USGS, 2012). Bu çalışmanın bir diğer amacı yukarıda adı geçen, ülkemize ait taşların jeolojik miras olarak algılanmasına yardımcı olmaktır. Toplum sahip olduğu değerlerin farkına vardıç̧a, onları koruma ve geliştirmede daha duyarlı olacaktır.

\section{JEOLOJİK MİRAS ve KÜLTÜREL JEOLOJI}

Bilimsel öneme ve belge niteliğine sahip, kaybolması durumunda bulunduğu yerin jeolojik geçmişini açıklamanın mümkün olmayacağı istif, kayaç, mineral, fosil topluluğu, yapı, doku, yerşekli vb oluşuklara jeolojik sit (= jeosit), yok olma tehdidi altında olanlara da jeolojik miras (= jeomiras) ad1 verilmektedir (www.jemirko.org. tr; www.progeo.se). 'Jeosit' bilimsel bir tanım ve fakat 'jeomiras' onun toplumsal ifadesidir. İnsanın kendisine atalarından kalan varlığa sahip çıkacağı varsayılarak, koruma ihtiyacını vurgulamak için bu şekilde isimlendirilmiştir (Kazanc1, 2010). Türkiye'nin Avrupa ile bütünleşme sağlayacak şekilde Jeolojik Miras Çatı Listesi mevcuttur (Theodossiou-Drandaki ve diğ., 2004; Kazanc1 ve Şaroğlu, 2009). Bu yazıda tanıtılacak olan doğal yapı taşları ProGEO (Avrupa Jeolojik Mirası 
Koruma Kurumu) jeosit ölçütlerine uymaktadır. Hepsi belli bir yöreye ve belli bir zamana ait özel oluşumlardır. Yokolma durumları söz konusu değilse de varlıklarının bilinmesi, sahip çıkılması ve gelecek nesiller için yeterli rezervin ayrılması gereklidir.

Son aylarda Türkiye'de "kentsel dönüşüm” gündemdedir. Gecekondular ve sağlıksız binalar yıkılacak, yerlerine yenileri yapılacaktır. Ümit edilir ki, bu kapsamda estetik yönü öne çıkan doğal taşların planlı şekilde kullanılması mümkün olur. Ülkemizde kişilikli kentlerin ortaya çıkmasına yol açabilecek böyle uygulamalar, başka ülkelerde çoktan başlamış ve artan şekilde teşvik edilmektedir (Heldal ve Neeb, 2000; BGS, 2011; USGS, 2012). Şehirlerin tescilli taşlardan oluşturulmasına katkıda bulunmak üzere, Jeolojik Mirası Koruma Derneği bu doğal taşları kendi listesinde jeomiras olarak kayda geçirmiştir. Yerel yönetimlerin de Türk Patent Enstitüsü'nde aynı taşlar için "coğrafi marka" tescili yaptırmaları için çabalarını sürdürmektedir.

İnsan yaşamı ile alakalı bütün doğal süreçlerin incelenmesi Kültürel Jeoloji kapsamındadır (Kazanc1, 2005; Altunel, 2012). Bu tanım Farrelly (2011)'nin “mimarlık tarihi doğal taş kullanım tarihidir" görüşü ile birleştirildiğinde, doğal yapı taşlarının kültürel jeolojideki yerinin büyüklüğü ortaya çıkmaktadır. Efes antik kenti, Ahlat mezartaşları ve kümbetleri, Mardin il merkezi veya Divriği Ulu Camii ve Külliyesi’ni Dünya Mirası listesine dahil eden özelliklerin bir kısmı sanatsal, diğeri ise bunları sağlayan taşlardır. Doğal taşlardan ileri gelen özellik ve güzellikler yerbilimcilerin sorumluluğundadır.

\section{Günlük yaşamda doğal taşlar ve terimler}

Doğal taşlar günlük yaşamın olduğu kadar ekonominin de önemli bir parçasıdır. Maliye
Bakanlığı'nın yabancı dilde hazırladığı bilgi

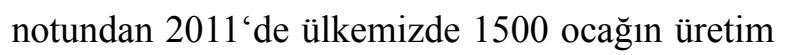
yaptığını, 2000 fabrika ve 9000 satış merkezi olduğu anlaşılmaktadır. Üretimin önemli kısmı ihraç edilmiş ve 1,7 milyar USD gelir sağlanmıştır (TR-ME, 2012). $\mathrm{Bu}$ gelişmede standartların varlığı (TS-EN-12440/2008) ve üreticilerin buna titizlikle uymalarının payı büyüktür (Büyükbağış, 2012; TSE, 2012).

Doğal taş sektörü ve piyasası son iki yılda, blok ve işlenmiş taşların yurtdışına (özellikle Çin'e) satılıyor olması nedeniyle çok canlıdır. Her türlü taşın piyasasının olması, bunlardaki madenciliğin göreceli kolay oluşu taşocağı işletmeciliğine talebi artırmaktadır. Ocaklardan söküm ve sökülen taşların işlenmesi için teknoloji devamlı yenilenmekte, yenilenen teknoloji ile daha çok üretim yapılmaktadır. $\mathrm{Bu}$ süreçte doğal taşın kullanım alanları çeşitlenmiş ve özel bir terminoloji doğmuştur. Terimlerin bazıları standartlara girmiş ise de (bkz. TSEN-12440/2008), büyük çoğunluğu salt kullanım yerini anlatmaktadır. Terimlerin bazıları şunlardır;

Yapı taşları; özel bir anlam yüklenmediği sürece binaların kaba iskeletlerinde (dış ve iç duvarlar) kullanılan doğal taşları anlatır.

Mermer; jeolojik anlamda değil de ticari anlamda kullanılan bir terimdir ve parlatılabilen bütün doğal taşlar bu adla anılmaktadır.

Süs taşları; kişisel eşya olarak veya dekorasyon amaçlı kullanılan taşlardır.

Kıymetli ve yarı klymetli taşlar; süs taşlarının bir alt grubu olmakla beraber çoğunlukla mücevherat olarak değerlendirilirler.

Kaplama taşları; ekseri binalarda iç ve dış cephe kaplamalarında kullanılan taşlardır. Çoğunlukla Kayrak taşı olarak pazarlanmaktadır.

Yantu taşları; heykelcilikte kullanılan taşlardır. 
Dekorasyon taşları; bina iç ve dış süslemelerinde kullanılırlar.

Dekoratif taşlar; doğrudan kendisi süs eşyası olan taşlardır, ekseri vazo, sehpa, çiçeklik olarak değerlendirirler.

Açık alan yapı taşlart; şehircilikte ve peyzajlarda kullanılan doğal taşlar olup parkbahçe taşları, meydan taşları, yol taşları, çeşme taşları ve heykel/anit taşları olarak alt gruplara ayrilmaktadir.

Tespih taşlart; el işlemeciliği taşları olarak da bilinirler.

Isı yalıtım taşları; yalıtım amacıyla kullanılırlar.

Fırın ve şömine taşlart; Son yıllarda çoğunluğu suni yolla üretilmekte olup bununla beraber doğal olanları da vardır.

Inşaat sektörü doğal taşlarl; başlıca beyaz mermer, renkli mermer, sert taşlar, traverten olarak dört grupta toplanır.

Ticari doğal taşlar; ocaklardan sökülüp satılan ve ürün devamlılı̆̆ 1 olan taşlardır.

Parlatılabilen doğal taşlar; doğrudan mermerleri ifade eden bir tanımdır.

Kesme taşlar; inşaata uygun boyutlarda hazırlanmış, ekseri kübik taşlardır. Yol döşemesi veya duvar yapımında kullanılır.

Kamu ve özel yapılarda doğal taşlar; kamu veya özel kurumlar tarafından inşa edilen, temsil özelliği olan ve/veya saygınlık için dikilen yapılarda kullanılan, kullanımı mimarı tarafından bizzat tarif edilen taşlardır. İç mekân ve dış mekân taşları olarak ayrılırlar.

Yukarıda belli bir sıra gözetilmeksizin listelenen terimler, doğal taşların son derece yaygın kullanıldığını ve hepsinin büyük ekonomik değere sahip olduğunu ortaya koymaktadır. Ancak bunlar arasında kültürel değer, bilimsel değer ve korunmaya vurgu yapan hiçbir terim veya tanım yoktur. Oysa doğal taşlar yerkürenin evriminin bir parçasını temsil ederler. Örneğin mermerler Paleozoyik, travertenler ise Kuvaterner için tipiktir. Bunların yalın doğal taş şeklinde değil, doğru jeolojik adları vurgulanarak anlatılması halinde daha geniş kitlelere ulaşabilir ve yurtdışında tanınma şansları artabilir. Yöresel ad ile jeolojik adları birlikte kullanılması sosyoekonomik anlamda daha önemli katkılar sağlayacaktır (Pivko, 2003).

\section{JEOLOJİK MİRAS VE MILLİ TAŞLAR}

Aşağıda kısaca tanıtılan doğal taşlar çeşitli yapıların ve sanat eserlerinin asıl malzemesi olmuş, kullanıla kullanıla daha çok tanınır ve tercih edilir hale gelmişlerdir. Bu taşlar bir anlamda artık milli taşlardır. Çünkü bu taşlarla inşa edilen pek çok eser kültürümüzün vazgeçilmez parçalarıdır. $\mathrm{Bu}$ taşlar aynı zamanda ülkemizin jeolojik miraslarıdırlar. Uluslararası terminolojiye göre doğru tanımlaması Jeomiras nitelikli doğal taşlar'dır. Kısaca Jeomiras taşlar da demek de mümkündür. Bunların en tanınmışları, bazı özelliklerine vurgu yapılarak aşağıda alfabetik sıra içinde verilmiştir (yöre adı ile anılan taşlar, nitelikleri bakımından benzersizdirler ve bu nedenle özel isimdirler. Dolayısıyla iki kelime olarak ayrı ve ilk harfleri büyük yazılmıştır: Ahlat Taşı, Nevşehir Taşı gibi) (Şekil 2-6).

\section{Ahlat Taşı}

Tip yeri: Çok tanınan bu taşın bulunduğu ve yaygın şekilde kullanıldığg yer Bitlis'in Ahlat ilçesidir (Şekil 1). Yöredeki çeşitli kültürlerin eserlerinde yer alır, belirgin olarak Selçuklu mezar taşları ve kümbetlerin yapımında kullanılarak dikkat çekmiştir (Şekil 2). Yöredeki görkemli bütün binalar bu taş ile yapılmıştır. 
Litolojisi ve işlenme özellikleri: Ahlat Taşı volkanik kökenli bir kayaçtır. Petrografik adı ignimbrittir (Şekil 2 a-d). Mikroskop incelemelerinde içinde az miktarda plajiyoklas, piroksen ve hornblend mineralleri bulunduğu görülür. Kaynaklaşma, yani volkanik tanelerin birbirine tutturulma oranı gri renklilerde çok belirgindir (Şekil 2a,b). Kırmızı renkli ignimbritlerde kaynaklaşma daha zayıf, bozuşma (alterasyon) daha ileridir. $\mathrm{Bu}$ değerli kültürel taşın tanıtman rengi kırmızının tonlarıdır (Şekil 2c,d). En yaygını kahverengimsi kırmızıdır. Diğer renkler ise açık sarı ve koyu gridir. Dikkat çekmesi nedeniyle küçük yapılarda kırmızı en tercih edilen yap1 taş1 iken, büyük binalarda diğer renkler de kullanılmaktadır. Ahlat Taşı olarak pazarlanan bazı volkanik taşlar ise tipik ignimbrit değil, içinde kayaç parçaları bulunan tüftür.

Benzer bazı doğal yapı taşları gibi, Ahlat Taşı'nın da en önemli fiziksel özelliği yüzeyaltı ocaklardan çıkarıldığında kolay işlenebilmesidir (Şekil 2c). Bunu sağlayan, birincil gözenekliliğe sahip dokusudur. Yani, taneler arasında çok küçük, kılcal boşluklar bulundurur. Zaten, ignimbriti oluşturan pümis tanelerinin kendisi gözeneklidir. $\mathrm{Bu}$ gözeneklerdeki su ve/veya rutubet taşın kolay işlenmesini sağlar. Bununla birlikte, Ahlat Taşı'nın su emme potansiyelinin göreceli yüksek olması yağışlı şartlara dayanımını düşürmektedir (Şimşek ve Erdal, 2004; Dinçer ve diğ., 2012). Tersine, yüzeyde uzun süre kuru kalan veya yapıda atmosfer ile temas eden kayanın suyu kaybolur, sertleşir. Dayanımı da artar.

Sahayayılımı ve rezervdurumu: Van Gölü kıyılarından başlayarak Ahlat çevresinde oldukça geniş bir alanda Ahlat Taşı işletmesi yapılmaktadır. Yani, görünüşte rezerv sorunu yoktur. Bununla birlikte kırmızı renkli olanını bulmak, özellikle işlenmesi kolay bloklar çıkarmak güçtür. Bunun temel sebeplerinden birisi uzun y1llardan beri devam eden kötü işletmeciliktir. İkincisi ise Ahlat Taşı'nı teşkil eden ignimbritlerin, alterasyon nedeniyle çoğu yerde toprağımsı hal alması ve blok vermez oluşudur. İlaveten işletmelerde büyük atıklar ve kayıplar olmaktadır. Günümüzde gittikçe artan atıklarının taş unu olarak beton içinde değerlendirilmesi üzerine çalışmalar başlamıştır (Erdal ve Şimşek, 2011). Bu olanaklı görünmektedir, çünkü ögütülmesi kolaydır.

Jeolojik özellikleri: Ahlat Taşı'nı teşkil eden ignimbritler Nemrut Volkanı'nın ürünleridir. $\mathrm{Bu}$ ilişki, önceki jeoloji araştırmalarının verileri ile (Yılmaz ve diğ., 1987) Ahlat taş ocaklarının yerleri karşılaştırılarak tarafımızdan kurulmuştur. Jeoloji incelemelerinde Ahlat Taşı'na değinme yoktur, ancak taş ocaklarının olduğu yerler Nemrut volkanizmasına bağlı kırıntılı püskürükler olarak haritalanmıştır. Ahlat Taşı'nı oluşturan piroklastikler, mevcut volkanostratigrafiye göre, volkanizmanın başlangıç dönemlerinde, erken Pleistosen'de yerleşmişlerdir (Yılmaz ve diğ., 1998). Bu bölgede kalmakla beraber Süphan volkanizması göreceli daha dar yayılımlıdır (F. Şaroğlu ile sözlü görüşme, 2013). Yakın zamanda gerçekleştirilen incelemelerde bu piroklastikler Nemrut İnimbritleri olarak adlandırılmış ve kaldera öncesinde meydana geldikleri belirtilmiştir (Karaoğlu ve diğ., 2005). Bu çalışmaya göre Nemrut İgnimbritleri üç fazda, en az on üç ayrı püskürmenin ürünlerini kapsamaktadır. Bunların çoğu kül, pümis ve skorya döküntüleri, bazıları da piroklastik akma şeklinde olmuştur. Jeomiras nitelikli kesimleri piroklastik akma süreçleriyle yerleşmişlerdir. 


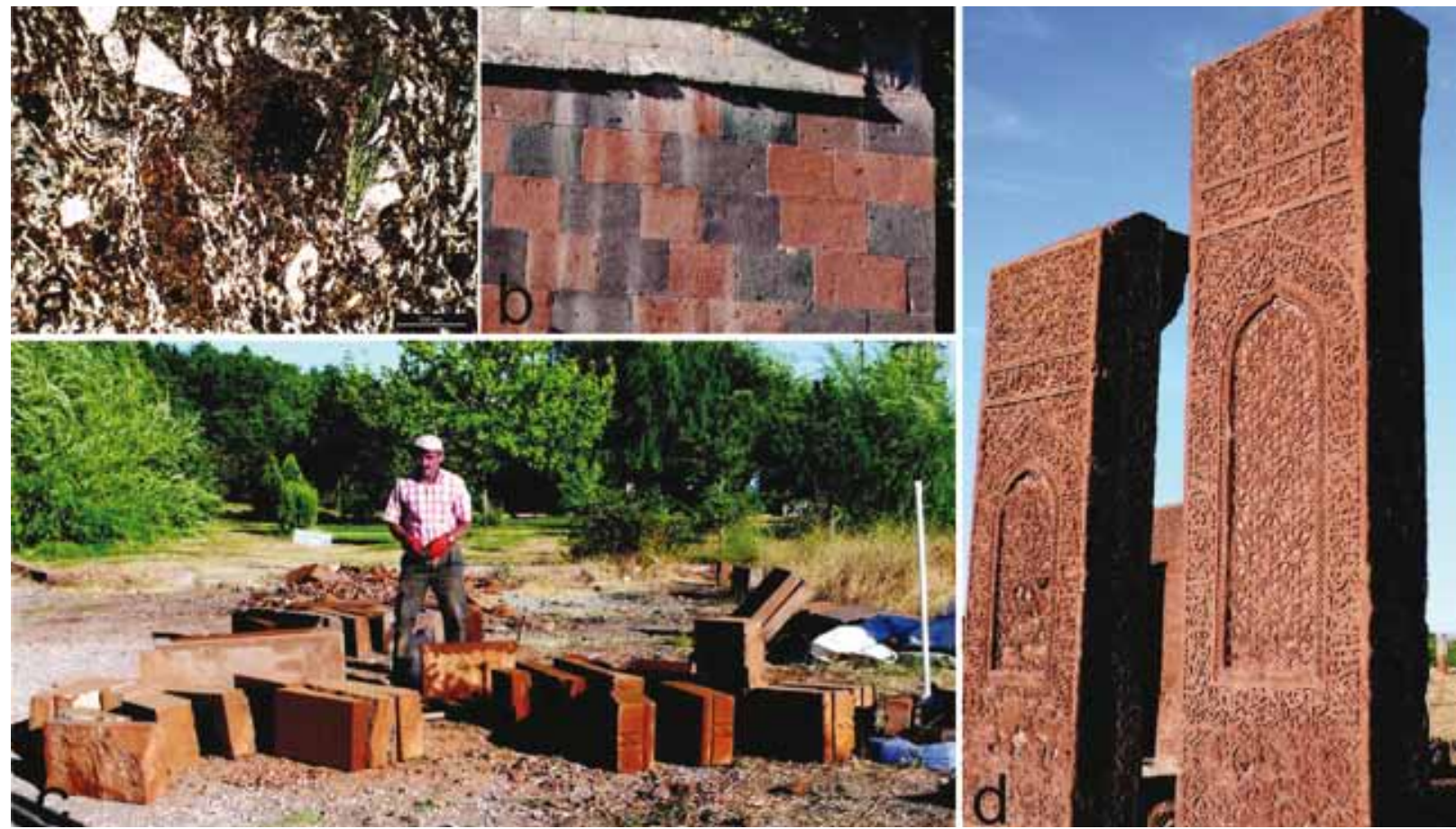

Şekil 2. Ahlat Taşı; a. İnce kesitteki görünüşü. Tipik ignimbrit dokusu dikkat çeker, b. Tarihi bir yapıda gri ve kırmızı renkli Ahlat Taşı’nın birlikte kullanımı, c. Ocaktan yeni getirilmiş ve testere ile kesilen kırmızı Ahlat Taşı blokları, d. Ahlat Taşı'ndan mezartaşları.

Figure 2. Ahlat Stone; a. Texture of the Stone in thin section, b. Gray and red Ahlat Stone in a historical building, c. Cutted blocks of the fresh Ahlat Stone, d. Tombstones by Ahlat Stone.

\section{Ankara Taşı}

Tip yeri: İsmindeki nitelemeye rağmen Ankara Taşı'nın tip yeri, daha doğrusu en iyi örneklerin çıkarıldığı ocakların bulunduğu yer, Ankara'nın Gölbaşı ilçesidir (Şekil 1). 1932‘de başkent Ankara'yı modern bir şehir olarak planlayan Alman mimar Hermann Jensen buradaki önemli binaların çevrede bol bulunan, güzel görünümlü bu kayalarla yapılmasını önermiştir (Atay, 1968). $\mathrm{Bu}$ ilk planın sonraki yıllarda bütünüyle terk edilmesine karşın, halen görkemini koruyan bazı eski binalar (Ankara Üniversitesi DTCF, Hukuk, Ziraat, Fen fakülteleri, Ziraat Bankası, Merkez Bankası) Ankara Taşı ile inşa edilebilmişlerdir (Şekil 3).

Litolojisi ve işlenme özellikleri: Ankara Taşı kendine özgü pembeliği bulunan andezittir
(Şekil 3). Pembe renk kayaç içinde yer alan plajiyoklaslardan ileri gelir. Bununla birlikte bütün Ankara taşları aynı renkte değildir. Gri renkte olanları da vardır, fakat tercih edileni pembe renklidir. Çoğu kez pembe ve gri renkli taşlar birlikte kullanılır (Şekil 3 c). Ankara taşı sert, sık dokuludur, fakat göreceli kolay işlenir. Gözenekli değildir. Bu nedenle dayanıklıdır. Islakken rengi parlaktır. Ekseri döşeme ve kaplama işlerinde tercih edilmektedir.

Saha yayulımı ve rezerv durumu: Ankara Taşı, İç Anadolu' da yaygın olan volkaniklerin (bkz Ercan, 1986) pembe olan Gölbaş1 andezitleridir (Şekil 1). Harita üzerinde yaygındır, fakat her yerde ocaklardan blok çıkarılamadığından rezervin sınırlı olduğu söylenebilir. Buna karşın işletme yoğundur ve daha hızlı üretim yalnızca taş 
ocağı ruhsatı almadaki güçlükler nedeniyle (şehir merkezine yakınlık, özel mülkiyet, orman ve sit alanı, çevre sorunları vb) sınırlanmaktadır.

Jeolojik özellikleri: Ankara çevresinde yaş aralığı olarak Geç Kretase'den Pliyosen'e kadar volkanik kayaç bulunmaktadır (Ercan, 1986; Tankut ve diğ., 1990). Bunların en yaygını ve belli bir topluluk oluşturanı Erken Neojen yaşlı Kızılcahamam veya Galatya volkanitleridir (Toprak ve diğ., 1996; Koçyiğit ve diğ.2003). Ayrıca Ankara-Haymana arasında, Ankara-Polatlı arasında Ballıkuyumcu köyü civarında, Mamak ilçesi civarında bazaltik, andezitik ve riyolitik bileşimde piroklastik ve lav akmaları şeklinde püskürük kayaçlar yer almaktadır. Bunların bir kısmı Tekke volkanitleri olarak adlanmış ve stratigrafik konumlarına dayanılarak Geç Miyosen yaşı verilmiştir (Yılmaz ve Çakır, 2007). $\mathrm{K}-\mathrm{Ar}$ yaşlandırmasında ise bunların bir bölümü Eosen olarak çıkmış ve birçok jeoloji haritasında ayırım yapılmaksızın hepsi birlikte haritalanmıştır (Seyitoğlu ve Büyükönal, 1995). Özetle, Ankara civarındaki volkanik kayaçlar bilinenlerden çok daha karmaşıktır, yaşı ve bileşimleri konusunda daha ayrıntılı çalışmalara ihtiyaç vardır. Ankara Taş1 olarak işletilen volkanitler ise Gölbaşı-BalaElmadağ arasında yamalar halinde görülür. Bunlar belli bir volkanik sistemin (örn. Kapadokya volkanik bölgesi, atı Anadolu volkanik bölgesi gibi) parçası olmaktan çok, çoğunlukla Erken ve Orta Miyosen yaşlı tekçe volkanik çıkışların, Geç Miyosen ve Pliyosen dönemindeki çökellerle üzeri örtülmüş temsilcileridir.

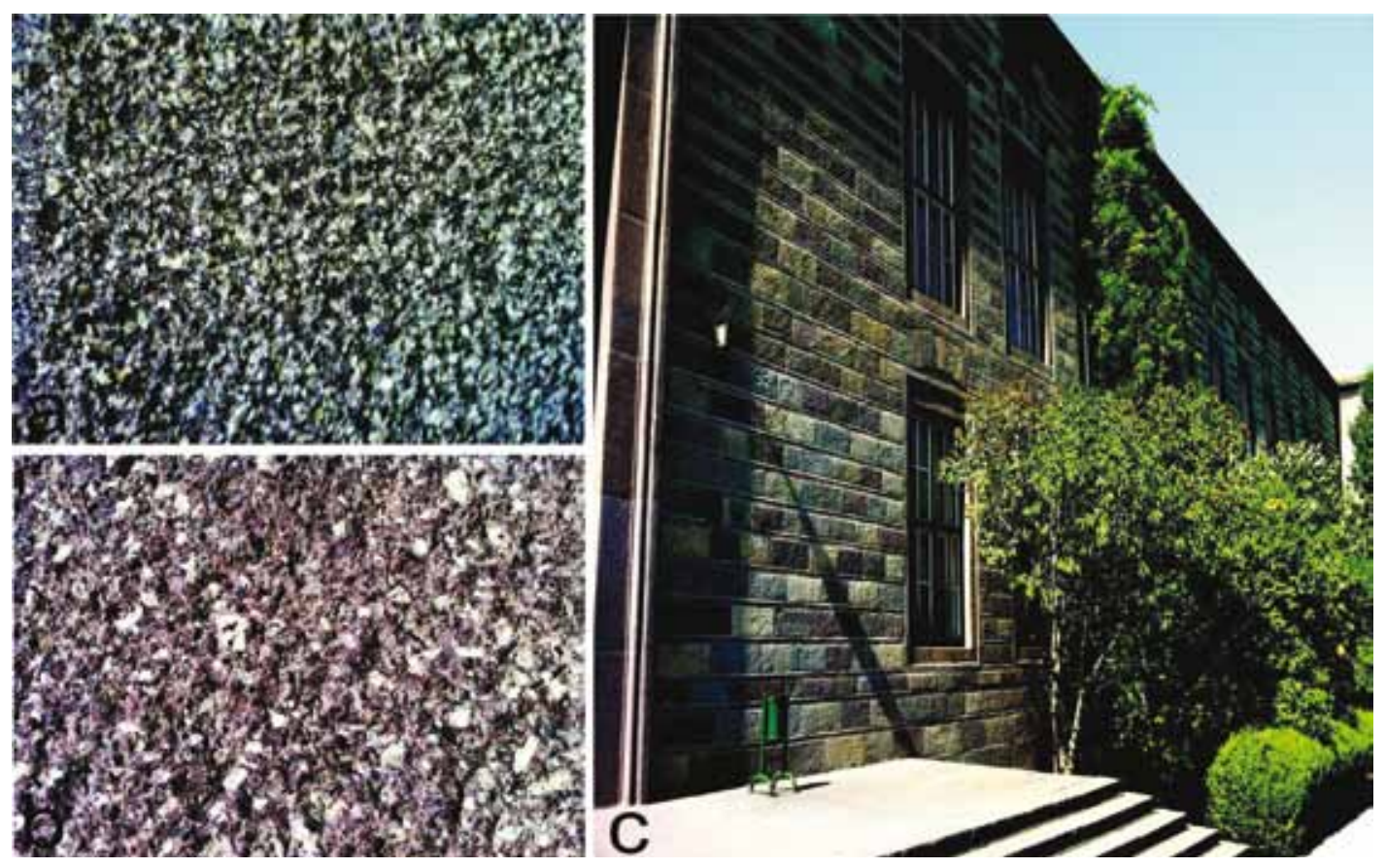

Şekil 3. Ankara Taşı ve genel görünümü; a. Gri renkli Ankara Taşı ince taneli ve sıkı dokuludur, b. "Ankarait" de denilen iri kristalli ve pembe renkli Ankara Taşı, c. Ankara Taşı'nın yapıdaki görüntüsü (A.Ü. Fen Fakültesi A Blok).

Figure 3. General appearance of the Ankara Stone; a. Gray Ankara Stone with tough texture, b. Pinkish Ankara Stone with large crystals described as "Ankaraite", c. Ankara Stone in walls of a building (Science Faculty of Ankara Univ, Block A). 


\section{Lületaşı (Eskişehir Taşı)}

Tip yeri: Adı bulunduğu şehir ile özdeşleşmiş olan Lületaşı, Eskişehir Taşı olarak da bilinir, ancak bu taştan üretilen el işleri, bilhassa lüle (pipo) o kadar tanınmış ve benimsenmiştir ki, yüzyıllardan bu yana Lületaşı olarak tanınmaktadır. Taş, hâlihazırda, yaygın olarak Eskişehir ilinin üç ayrı bölgesinde yeraltından çıkarılmaktadır (Şekil 1). Yüzeyde ocakları (açık ocak) yoktur. Üretimin verimli olarak yapıldığı yerler Alpu ilçesinin kuzey-kuzeybatısındaki Sepetçi-Marg1Söğütçü köylerinden oluşan Yakaboyu bölgesi ve Alpu güneybatısında Sarısu yatağı olarak bilinen İmişehir-Karatepe köyleri civarıdır. Ayrıca Eskişehir'in doğusunda Porsuk Barajı civarındaki Nemli bölgesidir. Bu bölgelerde kişisel gayretlerle ve güvensiz şartlarda, bazıları 300 metre derine inen ve buradan 150-200 metre yanal ilerleyen galerilerden çıkarılmaktadır. Yine de bir ocak sahibi olmak yerel halk için şans sayılmakta, çünkü önemli bir gelir kaynağı olmaktadır.

Litolojisi ve işlenme özellikleri: Lületaşı, magnezyumca zengin kildir. $\mathrm{Bu}$ taşı meydana getiren mineral, alfa-sepiyolit, fiziksel özellikleri bakımından eşsizdir; çünkü yumrular şeklinde bulunur, sertliği düşük olmakla beraber dağılgan değildir, şekil verilebilir. Onun yaygın türevi olan beta-sepiyolit ise fiziksel olarak lületaşından çok farklı, çoğunlukla tabakalar halinde yataklanmış, dağılgan, çeşitli sanayi dallarında kullanılan tiptir (Sabah ve Çelik, 1999). Lületaşının rengi genellikle beyaz, nadiren açık krem olur. Lületaş1 kamuoyu tarafından göreceli en iyi bilinen doğal taştır. Çünkü çoğu evde süs eşyası olarak bu taştan üretilmiş bir ürün, ekseri gösterişli bir pipo bulunur (Şekil 6c). Kayacın büyük kültürel geçmişi ansiklopedilere girmiştir, hakkında tarihi hikayeler vardır (Bilim, 1997). Hakkında fazla bilimsel inceleme olmasa da, toplumsal değeri yeni çalışmalarla gündemde tutulmaktadır (Zengin, 1955; Gül ve diğ., 2010; Taşlıgil ve Güven, 2011).
Lületaşının sertliği 2-2,5 arasıdır, bu nedenle işlenmesi çok kolaydır. İçindeki nem işlenmesini daha da kolaylaştırır. Lületaşı ocaklardan genellikle 10-15 cm civarında yumrular şeklinde çıkarılır. Parlatılabilir, boya ve cila tutar, ancak çoğunlukla doğal rengi tercih edilir. Bütün kil kayaçları gibi Lületaşı da atmosferik şartlardan etkilenir. Bu nedenle açık alanlarda kullanılması tercih edilmez. Bununla birlikte Hitit ve Frig kalıntıları arasında Lületaşından yapılmış ve bozulmadan kalmış eşyalara rastlanmıştır (Gül ve di.̆., 2010).

\section{Saha yayllmı ve rezerv durumu:}

Oluşumundaki olası öznellik nedeniyle Lületaşı yatakları geniş alana yayılmış değildir. Eskişehir Grabeni'nde (Ocakoğlu, 2007), ofiyolitli melanjın genç çökellerle dokanakları boyunca, 1-4 km'lik şerit içinde, seyrek yumrular halinde rastlanır. $\mathrm{Bu}$ ilişkiden Lületaşının yayılımının ofiyolitik ana kayanın varlığına bağlı olduğu görülmektedir. Bununla birlikte melanjın bulunduğu her yerde Lületaşı oluşmuş değildir. Oluşum yalnızca Eskişehir civarında görülür ve adeta Eskişehir'e bir hediye gibidir. Bilinen işletme yatakları ve köken ilişkisinden çıkan sonuç, Lületaşı rezervinin son derece sinırlı olduğudur. Üretim de sınırlıdır ve yurtiçi talebi güçlükle karşılar. $\mathrm{Bu}$ nedenle olsa gerek, yurtdışına doğal taş olarak satışı yasaklanmıştır (Bozkurt, 1989; Taşlıgil ve Güven, 2011).

Lületaşı hakkında yaygın internet dosyası vardır. Bunlar kadar olmasa bile, çoğunluğu sosyal bilimlerden gelen yazılı kaynak bulunmaktadır, ancak bunlardaki jeolojik bilgi son derece sınırlıdır ve genellikle birbirinden aktarmadır. Örneğin hiç biri ayrıntılı jeoloji haritası bulundurmaz, yatakların stratigrafisini ve ayrıntılı petrojenezini kapsamaz. Önceki çalışmalar çoğunlukla sorunlara değinmektedir (bkz. Petraschek, 1963; Bozkurt, 1989 ve bunlardaki kaynaklar). Bu 
nedenle şimdiye kadar ne kadar üretim yapıldı ve ne kadar kaynak kaldığı bilinmemektedir.

Jeolojik özellikleri: Yukarıda belirtildiği gibiLületaşı üretimisınırlı biralandayapılmaktadır. Alfa-sepiyolitin kaynağı ofiyolitik kayalar olmakla beraber, oluşum daha genç kırıntılı çökeller içine yerleşmiştir. Mevcut üretimin yapıldığg bu çökellerin yaşı, jeoloji haritalarında Pliyosen olarak görünmektedir (MTA, 2002a; Ocakoğlu, 2007; Şengüler ve Izlad1, 2013). Ancak değinilen kaynaklarda belirtildiğine göre, Eskişehir havzası veya grabenindeki Pliyosen istifinin kalınlığ 50 metreden azdır. Halbuki şimdilerde üretim kuyularının derinliği 300 metreye ulaşmıştır. $\mathrm{Bu}$ durum, Lületaşı'nın belli bir stratigrafik döneme ait olmayıp, ofiyolit dokanağında biriken çeşitli yaşlardaki (Pleyistosen, Pliyosen, Miyosen) kırıntılı çökeller içine yerleştiğini işaret etmektedir. Tarafimizca yapılan incelemelerde de, bazı Lületaşı yumrularının ortalarında manyezit kalıntıları gözlenmiştir. Bu kalıntılar Lületaşı ustaları tarafından "taşın özü" veya "kirlilik" olarak tarif edilmektedir. İlginçtir ki, Lületaşı üretimi yapılan bölgelerdeki ofiyolitik kayalarda ince bant veya damarlar halinde manyezit seviyeleri bulunmaktadır. Hatta bunlar yakın tarihlerde ruhsatlandırılmış ve işletilmeye çalışılmıştır (Y.Suludere; sözlü görüşme, 2013). Çok büyük olasılıkla, bu manyezitli seviyeler parçalanıp değişik boydaki taneler halinde çökel ortamına aktarılmakta, burada zamanla alterasyona uğrayıp lületaşı halini almaktadırlar. Bu olası ilişkiyi Petraschek (1963) de fark etmiş fakat sonradan şüpheye düşmüştür. Üretim yapılan yerlerdeki tortul birikimin doku ve istif özellikleri, depolanmanın kolüvyon, alüvyon yelpazesi veya örgülü akarsu süreçleriyle olabildiğini işaret etmektedir. Manyezitten Lületaşı'na dönüşmede yersel özellikler de (fay veya fay zonları, yeraltı suyu dolaşımı, termal su varlığı vb) önemli rol oynamış görünmektedir (Sabah ve Çelik, 1999).

\section{Midyat Taşı}

Tip yeri: Çok az doğal oluşum Midyat Taşı kadar şans ve şanssızlığı birlikte yaşar. Çünkü taş mimarisi ile dünyaca ünlü Mardin şehri ve neredeyse güneydoğu Anadolu'daki eski yeni bütün önemli binalar Midyat Taşı ile yapılmıştır, ancak Midyat Taşı'nın kendisi eserler kadar tanınmış değildir. Özellikle de bu açıdan yerbilimcilerin dikkatini çok az çekmiştir. Doğal taşın tip yeri ve en iyi blokların çıkarıldığı alan, taşa adını veren Midyat ilçesi ve civarıdır (Şekil 1). "Mardin Taşı", hatta "medeniyetler taşı" olarak da anılmaktadır (Önenç ve diğ., 2006), ancak bu daha çok Mardin'deki taş yapıların ünü dolayısıyladır. Çünkü Mardin Merkez civarında Tersiyer birimleri göreceli sinırlı alandadır (bkz. MTA, 2002b). Midyat Taşı üretimi, tüketimin en yaygın olduğu Midyat çevresinde yoğunlaşmıştır.

Litolojisi ve işlenme özellikleri: Midyat Taşı yer yer dolomitik, ince taneli, gözenekli kireçtaşıdır. Orta-Üst Eosen yaşlı Midyat Formasyonu'ndan üretilmektedir (Şekil 4a). Bu birimin genel litolojisi bolca neritik ortam fosili (Rotalia, Operculina, Amphystegina, Assylina vb.) bulunduran, ekseri mikritik, daha az oranda sparitik kireçtaşlarıdır (Özkaya, 1974). Çoğu yerde bol kırıklıdır ve yoğun karstlaşma nedeniyle içinde küçük ve orta boy mağaralar oluşmuştur. Yeni açılmış yarmalarında açıkça belli olduğu gibi, bu ikincil etkilerle breşik görünüm kazanmıştır. Ocakların sayıları talebe göre değişmektedir. Örneğin son iki yıldır Midyat'taki ocak sayısı dört, taş işleme atölyesi sayısı 15 ile sınırlı kalmıştır (Şahin ve diğ., 2013). Ocaklardan blok çıkarılması yüksek devirli bıçaklarla kesilerek yapılmaktadır. Buralarda taşlar tüketiciye iri parçalar halinde veya istenilen ölçülerde hazırlanmış olarak sunulmaktadır.

Ocaklardan çıkarılan Midyat Taşı beyaz, sarımsı beyaz veya krem renklerdedir. Ancak bu 
renk yüzey şartlarda zaman içinde kısmen koyulaşır ve kırmızımsı hal alır (Şekil 4b). Bu durum içinde eser miktarda bulunan demir nedeniyledir. Midyat Taşı gözeneklidir ve ağırlığının \%10'u kadar su bulundurur. $\mathrm{Bu}$ nemlilik dolayısıyla metal testere ile kesilebilir, kazllabilir, delinebilir. Suyunu kaybettikten sonra sertleşir ve işlenemez hale gelir, yalnızca kırılabilir. Kuru halde iken ortalama özgül ağırlığı 2,2 g/ $\mathrm{cm}^{3}$, ortalama birim hacim ağırlığ $1,6 \mathrm{~g} / \mathrm{cm}^{3}$, dayanımı ise yapılarda kullanım için verilen sınırlar içindedir (Kaya, 2008). Su emme kapasitesi (gözeneklere giren suyun donma ile yaratabileceği çatlak vb açısından önemli) standartlarda verilen değerlerin içinde olup iç ve dış cephelerde kullanılması uygundur. Aynı şekilde 1sı1 iletkenliği ve 1sı yayılım değerleri standartlar içinde ve iyi kaliteli beton seviyesindedir (Adin, 2007).

Yerinde aldığımız bilgilere göre Midyat Taşı'nın kullanımı son yıllarda yapılardan ev ve süs eşyası yapımına, özellikle heykelciliğe doğru değişim içindedir. Bunlarda işleme kolaylığını korumak için, ocaklardan alınan küçük bloklar atölyelerde suyunu kaybetmeyecek şekilde korunmaktadır.

Saha yayılımı ve rezerv durumu: Midyat Taşı'nın üretildiği Midyat Formasyonu güneydoğu Anadolu'da çok geniş alanlara yayılır. Siirt, Mardin, Urfa, Gaziantep ve Kilis illerinde aynı formasyon ve yanal eşdeğerleri yüzeylemektedir (MTA, 2002b). Bununla birlikte, birimin ileri derecede kırıklı ve çatlaklı durumu, karstlaşmanın da yaygın olması dolayısıyla her yerde üretim yapılması söz konusu değildir. Ayrıca, işlenebilir nemlilikte olması için yüzey altında ve yatay konumda bulunması gerektiğinden rastgele yerlerde ocak açılamaz. Bütün kısıtlamalara karşın, herhangi bir hesaplama ve planlama yapılmış değildir, ancak rezerv sıkıntısı olduğu söylenemez. Burada dikkat çeken bir hususu belirtmek gerekir;
Şanlıurfa civarında, Midyat Formasyonu'nun yanal eşdeğerleri içine açılmış çok sayıda "kapalı" taşocağı bulunmaktadır. Kendi tespitlerimize göre büyüklerden biri $150 \mathrm{~m}$ uzunlukta, $70 \mathrm{~m}$ genişlikte ve $25 \mathrm{~m}$ yüksekliktedir. Bunlar adeta orta büyüklükte yapay mağaralardır ve hemen hepsi yerel halk tarafindan kullanılmaktadır. $\mathrm{Bu}$ durum Şanlıurfa civarındaki eski yeni taş yapıların oluşturulması için bu kapalı ocaklardan üretim yapıldığını işaret etmektedir. İlginç bir gelişme olarak, son y1llarda Mardin ve Midyat'a Şanlıurfa'dan taş bloklar götürülmekte, oralarda Midyat Taşı olarak işlenmektedir. Benzer doğal taş nakli geçmişte de yaşanmış olabilir. Kesin olan, Şanlıurfa çevresindeki mağara halindeki eski taş ocaklarının hem doğal hem kültürel miras olduklarıdır.

Jeolojik özellikleri: Midyat Formasyonu ve beraberindeki otokton Tersiyer birimleri Arap Platformu üzerindeki bir sığ denizin ürünleridir (Özkaya, 1974; Perinçek ve diğ., 1992) (Şekil 4a). Bunlar allokton Kretase birimleri üzerine otururlar. Mardin civarından güneye ve batıya doğru çok geniş alanlara yayılmışlardır. Hatta bir bölümü Kerkük petrollerinin hazne kayaları durumundadır (Nairn ve Alsharhan, 1997). Gölbaş1-Gerger arasinda bu Tersiyer birimleri Midyat Grubu altında toplanmış, Midyat Formasyonu eşdeğeri tortullar ise Hoya Formasyonu olarak adlandırılmıştır (Sungurlu, 1972). Son yıllarda Nizip-Kilis civarındaki yüzlekleri Gaziantep Fm olarak adlanmakta, bunlardan üretilen doğal yapı taşları Havra Taşı adıyla pazarlanmaktadır (Önenç ve diğ., 2006). Geniş yayılımı dolayısıyla Midyat Formasyonu (= Hoya Fm)'nun stratigrafik kalınlığı değişkendir. Genel olarak doğudan batıya doğru kalınlaşır, 200 metreden 650 metreye kadar çıkar. Midyat Formasyonu Mardin civarında tümüyle karbonatlardan kurulu iken, kalınlığının $\operatorname{arttığ} 1$ yerlerde ince seviyeler halinde kırıntılı 


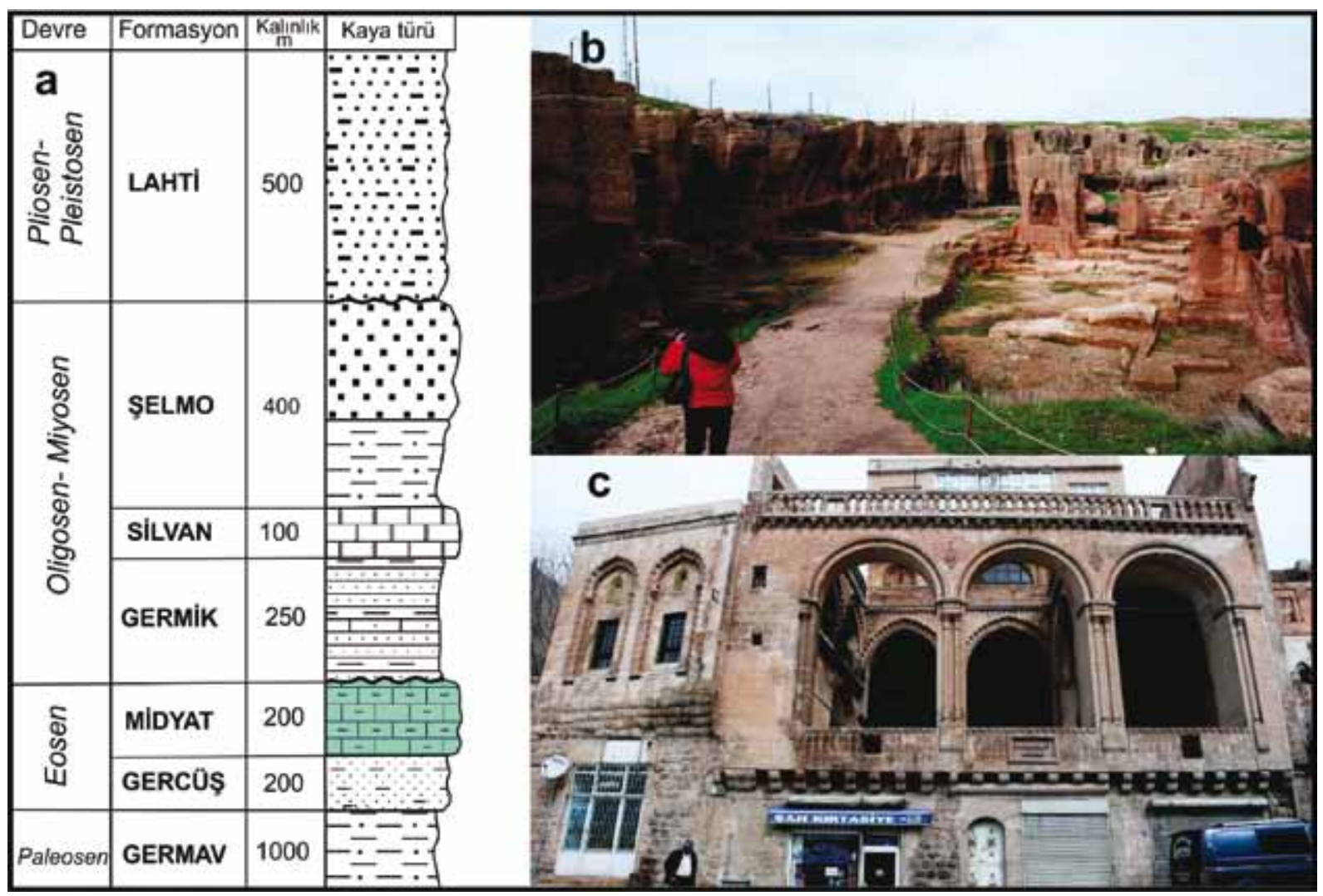

Şekil 4. Güneydoğu Anadolu otokton birimlerinin stratigrafik durumu ve Midyat Formasyonu (mavi boyalı) (Özkaya 1974), b. Midyat Formasyonu (Midyat Taşı) içine oyulmuş Dara antik kentinin mezarlığı. Yerleşimin kırmızıya çalan renk dikkat çekiyor, c. Midyat Taşı ile yakın zamanda inşa edilmiş, süslemeli, bej renkli bir konak (Midyat).

Figure 4. Midyat Formation (in blue) and stratigraphy of the authocthonous units in souteastern Anatolia (from Özaya 1974), b. Cemetary of Dara city (antic) hosted in Midyat Fm. Note the reddened colour of the settlement, c. A new and large house built by Midyat Stone. See the cream colour of the building.

tortullar bulundurduğu gözlenir. Aynı nedenle olsa gerek, bazı yerlerde Tersiyer istifi Orta Eosen-Erken Miyosen arasinda devamlı iken bazı yerlerde Midyat Formasyonu alttan ve üsten uyumsuzlukla kesilmiştir (Perinçek ve diğ., 1992). Bunlar depolanma ortamlarının ve depolanmayı kontrol eden tektonizmanın yerel farkl1lıkları sonucu olsa gerektir.

\section{Nevşehir Taşı}

Tip yeri: Ülkemizin göreceli çok kullanılan, fakat bir o kadar az tanınan volkanik kökenli bu doğal taşının tip yeri, Nevşehir-Ürgüp-Avanos arasında kalan sahadır. Burası aynı zamanda Kapadokya Volkanik Provensi içindeki çeşitli birimlerin en iyi yüzeylendiği alandır. Ticarileşmede kolaylık olması için il adı verilmiştir (işletmecilerden sözlü bilgi). Egemen renginin pembemsi bej olmasina karşılık, alterasyon durumlarına bağlı olarak çeşitli renklerde de bulunabilir ve bunların her birine ayrı ad verilmiştir (damarlı, mortaş, sarı, Kapadokya beji, gül kurusu, vişne; Korkanç, 2007). İşletme açık ocaklarda, önemli miktar örtü kaldırılarak yapılır. Ayrıca bölgedeki yoğun turizm 
faaliyetleri ve çok sayıdaki sit alanı nedeniyle üretim sınırlaması vardır.

Nevşehir Taşı'nın da içinde bulunduğu Kapadokya Volkanik Provensi'nin bu bölümü, Ürgüp Formasyonu olarak haritalanmıştır. Geç Miyosen-Pliyosen yaşlı birim, gölsel çökellerle ayrilır ve her biri ayrı adlarla anılan on bir adet ignimbrit seviyesi bulundurur. En altındaki Kavak İgnimbiritidir (Gevrek, 1997). Nevşehir Taş1 Kavak İgnimbiriti’nden üretilmektedir (Şekil 5a).

Litolojisi ve işlenme özellikleri: Nevşehir Taşı esas itibariyle ince taneli piroklastik kayaçtır. Bileşiminde fazlaca pümis bulundurması ve zayıfça kaynaklaşmış olması dolayısıyla, petrografik bakımdan ignimbrit olarak tanınır (Kavak Ignimbriti). Hammadde olarak mühendislik özellikleri ve kimyasal bileşimi Korkanç (2007) tarafından incelenmiştir. Buradaki verilere göre \% 20 civarında etkin gözenekliliği vardır ve yine bu oranda su emer. Dayanımı düşüktür. Bileşimindeki $\mathrm{SiO}_{2}$ oran1 \% 66-78, $\mathrm{Al}_{2} \mathrm{O}_{3}$ oran1 \%13-17, en önemlisi ateşte kayıp oranı $1000{ }^{\circ} \mathrm{C}$ ' de \% 6-9 civarındadır. Porfirik dokusu tipiktir (Şekil 5).

Kavak ignimbritinin, dolayısıyla Nevşehir Taşı'nın petrografisi yörelere göre değişir. Bir başka ifade ile ticari olarak farklı adlarla anılan Nevşehir Taşlarının yapısındaki camsı malzeme, pümis, kayaç parçası, kristal (bolluk oranlarına göre sirasiyla plajiyoklas, biyotit, amfibol, piroksen, sanidin, kuvars) varlığı değişkendir. En çok üretilen sarı ve Kapadokya beji olarak adlanan taşlardır.

Nevşehir Taşı'nın bütün tipleri kolay işlenir (Şekil 5c). Gözenekliliği ve yüksek su emmesi nedeniyle dış cephelerde fazla tercih edilmez.

Saha yaylımı ve rezerv durumu: Kavak İgnimbriti Nevşehir, Ürgüp, Avanos civarında çok geniş alanlara $\left(2600 \mathrm{~km}^{2}\right)$ yayılımlıdır ve yaklaşık $80 \mathrm{~km}^{3}$ kayaç hacmi olduğu tahmin edilmektedir (Temel ve diğ., 1998). Bu büyük bir rakamdır ve ilk bakışta doğal taş rezervi sorunu olmadığı şeklinde yorumlanabilir. Ancak, yukarıda değinildiği gibi birim, bu bölgedeki Neojen volkanotortul istifinin (Ürgüp Fm) en yaşlı bölümüdür, dolayısıyla üzerinde kalın bir birikim vardır. Kavak İgnimbiriti istifin derince yarıldığ 1 yerlerde yüzeylemiştir veya taş ocağ olarak işletilebilir durumdadır. Özetle, Kavak İgnimbriti için verilen hacmin bütünü Nevşehir Taş1 rezervi değildir. Mevcut yüzlek durumuna bakarak rezervin sınırlı olduğu söylenebilir.

\section{Jeolojik özellikleri: Aksaray-Niğde-} Kayseri-Kırşehir arasında kalan bölgenin adı olan Kapadokya, birbirini izleyen patlamalı volkanik ürünlerin biriktiği yer olmuştur (Kapadokya Volkanik Provensi). Volkanotortul istiflenmeye dayanarak söylenebilir ki, burada yaygın iki lav akması üzerine (Erdaş andeziti, Damsa lavları) oturan 11 ayrı volkanizma gelişmiş ve her biri geniş alanlara yayılan ignimbritler üretmiştir (Gevrek, 1997; Aydar ve diğ., 2012). Her bir volkanik evreden sonra bölgeye geniş bir göl yerleşmiş, sonraki volkanizma ile bu göller ortadan kalkmıştır. $\mathrm{Bu}$ durum ignimbritler arasındaki birkaç metrelik göl tortulları ve eski toprak (paleosol) oluşumları ile belirgindir. Kapadokya bölgesindeki volkanik çıkış merkezleri çok sayıdadır. Kuvaterner yaştakiler maar, tüf konisi ve lav konileri olarak arazide kolayca ayırt edilir. Geç Miyosen ve Pliyosen yaştakilerin çıkış merkezleri üst üste gelen volkanik yerleşme ile örtülmüştür, ancak Acıgöl ortada kalacak şekilde 100 km çapındaki Nevşehir kalderası bu çok büyük volkanik gelişimin merkezi olabilir (Gevrek, 1997; Temel ve diğ., 1998; Gevrek ve Kazanc1 2000).

Kavak ignimbriti, adını birimin en iyi görüldüğü yer olan Kavak Köyü'den almıştır. Radyometrik verilere göre 9,13 ile 9,43 my aras1 
yaştaki bir patlama ile meydana gelmiş ve çevreye yerleşmiştir (Aydar ve diğ., 2012). Çıkış merkezi, tane boyu büyüklüğüne dayanarak, Nevşehir civarında olmalıdır (Gevrek, 1997). Buradan kuzeye doğru yayılmıştır. Bu yayılış biçimi, Geç Miyosen'de bir dönem arazinin güneyden kuzeye doğru eğimli olduğunu işaret etmektedir.
Türkiye doğal taşları içinde belki de en çok tanınanı Oltu Taşı'dır; çünkü bu taş ile yapılan başta tespih ve pipo olmak üzere birçok el ve süs eşyası, kültürümüzün parçası olarak eskiden beri yaygın şekilde kullanılmaktadır (ayrıntılar için bkz Alpaslan, 2010) (Şekil 6b). Oltu Taşı'nın iyi tanınmasına yol açan önemli etken, bu taşın
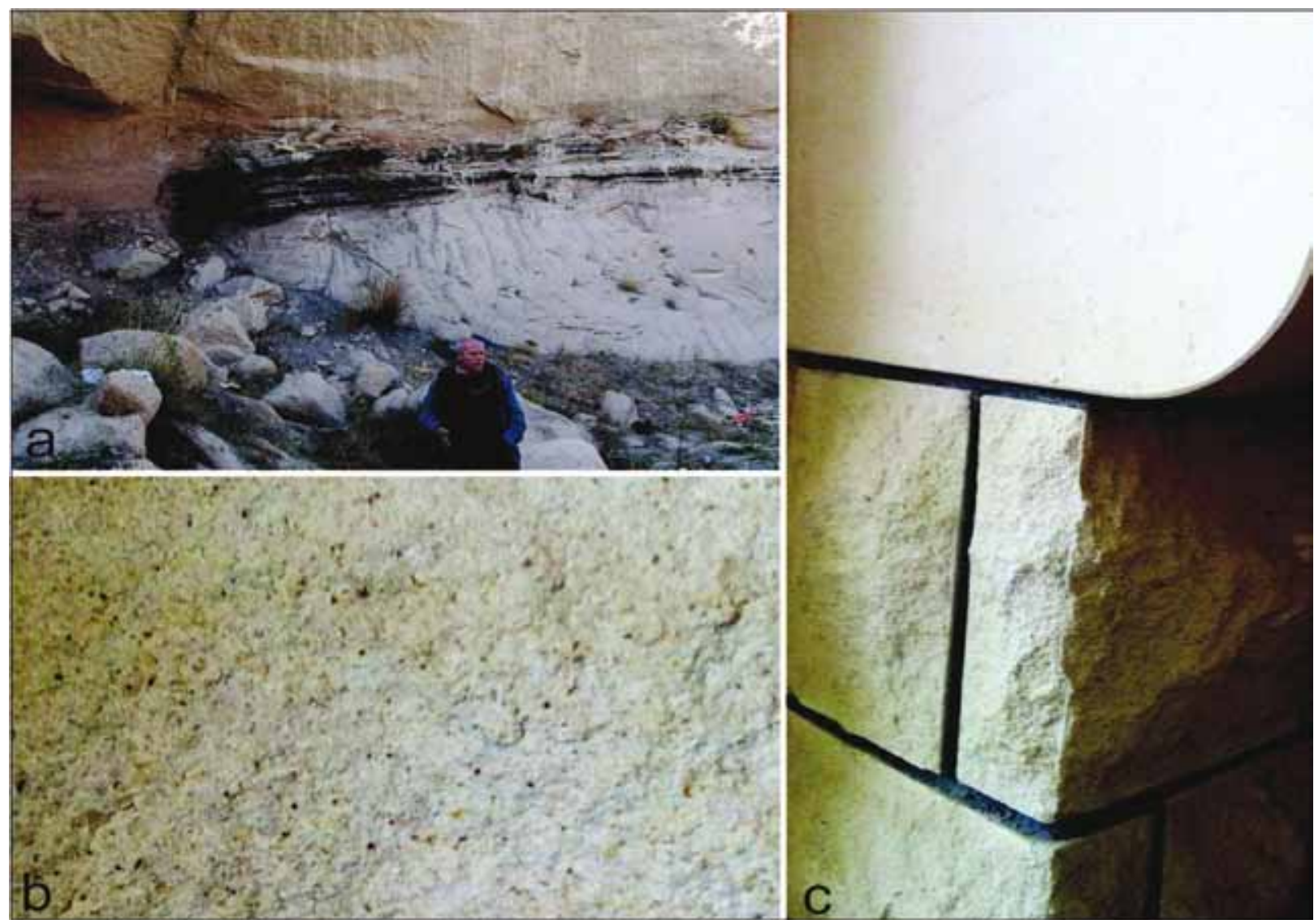

Şekil 5. Nevşehir Taşı; a. Bu taşın üretildiği Kavak İgnimbritinin saha görüntüsü, b. Nevşehir Taşı'nın el örneğindeki ince taneli dokusu, c. Parlatılmış (üstte) ve doğal haldeki (altta) tipik Nevşehir Taşı örnekleri.

Figure 5. Nevşehir Stone; a. Kavak ignimbrite which is the main rock of the Stone, b.. Fine-grained texture by hand sample of the Nevşehir Stone, c. Polished (upper) and natural (lower) surfaces of the Nevşehir Stone.

\section{Oltu Taşı}

Tip yeri: Oltu Taşı'nın tip yeri, üretiminin yapıldı̆̆ Erzurum'un Oltu ilçesidir (Şekil 1). Erzurum Taşı adı verilmiş ise de bu isim benimsenmemiş ve Oltu Taşı olarak tanınmaya devam etmiştir. ülkemizde göreceli erken dönemde bilimsel olarak ele alınmasıdır. Özellikle Maden Tetkik ve Arama Genel Müdürlügü (MTA) tarafindan yürütülen jeoloji çalışmaları ve bireysel araştırmalar ile Oltu Taşı yatakları, yatakların diğer birimlerle ilişkisi, 
petrografik ve kimyasal özellikleri belgelenmiştir (Zengin, 1955; Konak ve diğ., 2001; Karayiğit, 2007; Hatipoğlu ve diğ., 2012; Toprak, 2013). Günümüzde Oltu Taşı işletmeciliği, Erzurum ve ilçeleri için ekonomik ve kültürel faaliyetlerin odağı durumundadır

Litolojisi ve işlenme özellikleri: Oltu Taş1 çok yüksek kalorili kömür ve/veya linyittir. El örneklerinin lifsi dokusu bunu açıkça ortaya koyar. Yerel halk ve folklor araştırmacıları "karakehribar" adını tercih ederler. Bu konuda iyi bir derleme Doğanay (1997) tarafından yapılmıştır.

Oltu Taş1 yoğunluğu 1,25 gr/ $/ \mathrm{cm}^{3}$, sertliği 2, kalori değeri 8000 civarında, sarı, açık ve koyu kahve, siyah renklerde olabilen organik kökenli, doğal bir taştır. Yataklardan boyu 1-6 $\mathrm{cm}$ arasında yumrular halinde çıkarılır. Kırılma yüzeyleri konkoidal biçimdedir. İçinde az oranda pirit (demirsülfür) bulunur. Değişik Oltu Taş1 örneklerinde ölçülen yansıma değerleri (reflection values, $\mathrm{R}_{\max }$ ) ortalamas $1 \%$ 0,405 olup, organik taş olarak "alt bitümlü kömür” grubuna düşmektedir (Toprak, 2013). İşlenmesi kolaydır; kesilebilir, delinebilir, parlatılabilir. Genellikle metallerle birlikte kullanılarak eşya çeşitlenmesi sağlanır (Alpaslan, 2010). İşlenmiş Oltu Taşı’na parlaklığı veren odunsu yapısı ve geçmişte geçirmiş olduğu düşük metamorfizma şartlarıdır. Obsidiyen benzeri konkoidal kırılması da metamorfizmaya uğradığını ortaya koymaktadır. Hemen bütün örneklerde az çok rastlanan ve büyük olasılıkla bakteri kökenli olan (framboidal) piritler, Oltu Taşı'nın, başlangıçta bataklık ortamlarında, kömür olarak depolandıklarının işaretçisidir. Pirit oranı fazlalaştıkça, Oltu Taşı'nın mat görünümü de artmaktadır (Karayiğit, 2007; Toprak, 2013).

Saha yayllım ve rezerv durumu: $\mathrm{Bu}$ doğal taş, Oltu ilçesinin kuzeydoğu ve güneybatı kesimlerinde, yaklaşık $20 \mathrm{~km}$ lik bir uzanımda gözlenir. Burası Doğu Pontidler'de "Olur-Tortum
Tektonik Zonu" daki Olur Birliği'nin Malm yaşlı çökelleridir (= Olurdere Formasyonu) (Konak ve diğ., 2001). Olurdere Formasyonu iki adet yüz binlik paftaya yayılan (Oltu G47, Oltu G48) volkanik arakatkı1ı kırıntılı kayaçlardan oluşmaktadır (Konak ve Hakyemez, 2008; 2009). Oltu Taşı kırıntılı tortul kayaçlar arasında ince seviyeler halinde bulunan kömür damarları içinden çıkarılır. Belirtmek gerekir ki, kömürlerin tümü Oltu Taşı değildir. Kömürlü tabakalar eğimli, yer yer kıvrımlıdır, bu yüzden bulma ve iletme zorlukları vardır. Yerel halk tarafından güvenli olmayan ocaklardan çıkarılır. Uzun yıllardır yapılan işletme nedeniyle rezervler çok azalmıştır. Sürdürülebilirlik açısından, Lületaşı'nda olduğu gibi, arama, işletme ve ticaretinin daha kontrollü yapılması gerekmektedir.

Jeolojik özellikleri: Oltu Taşı'nın jeolojisi, onu içinde bulunduran Olurdere Formasyonu ile açıklanır. Bu birim, Bozkuş (1991)'de tanitılan Oltu-Narman Havzası'nın kömürlü tortullarına mesafe olarak yakın ve fakat stratigrafik olarak çok daha yaşlıdır. 1500 metre kalınlığı ile Olurdere Fm, neredeyse bütün Geç Jura devri boyunca bugünkü doğu Anadolu'yu da kaplayan denizin önce sığg, giderek derinleşen ortamlarında çökelmiştir (Konak ve diğ., 2001). Çoğunluğu alt seviyelerde olmak üzere yer yer çakıltaşı ve volkanit ara düzeyleri bulundurmasına karşılık, asıl oluşturucu litoloji yer yer tekçe bulunan kumtaş1-silttaşı-marn tabakaları ve bunların birlikte ardalanması şeklindedir. Kömür bantları ve Oltu Taşı yumruları göreli sı̆̆ kesimde çökelmiş kalın kumtaşları arasındaki killi silttaşı tabakaları arasında yer alır. Birimin asıl litolojiden farklı kayaçları olup "volkanit üyesi” olarak ayrılan andezit ve bazalt lavları, stratigrafik olarak değişik düzeylerde bulunur, üst seviyelere doğru ise yastık lavlar halindedir (Konak ve diğ., 2001). Paleocoğrafik bakımdan birim deltayik tortullarla 
başlayıp denizaltı yelpazesi şeklinde yerleşen fliş oluşumuna geçer. Çoğunluğu fliş içinde olan konglomeralar kismen olitostromlar kismen de denizaltı yelpazesinin yakınsak kısımları olarak depolanmıştır.

Kömürlerin bir kısmı deltayik istifte, bir kısmı da bunlardan taşınarak denizaltı yelpazesi içinde depolanmıştır. Bu ikinciler seyrek ve çok ince seviyeler halindedir. İlginç olan, bir kısım kömürlerin genelde linyit olmalarına karşın aralarında onlardan farklı yapıya sahip Oltu Taşı'nın oluşabilmesidir. Yüksek 1s1 kömürlü oluşuklarda termal metamorfizmaya yol açmış görünmektedir. Böyle bir oluşumun örnekleri, yani göreceli yüksek 1sının Geç Holosen yaşlı turbaları bile yersel olarak yüksek kalorili kömürlere dönüştürdüğü, Kapadokya'da bilinmektedir (Kazanc1 ve diğ., 1995; Kazanc1 ve Gevrek, 1996). Bu gelişmede önemli rolü, Olur-Tortum Zonu'nun güneyindeki Kuzey Anadolu Ofiyolit Zonu ile Alt Eosen'den itibaren gelişen çarpışması sırasında, iki zon arasındaki devasa tektonik hattın kenarında kalan Olurdere Formasyonu'nun tektonik, hatta, komşu kısımlarında meydana gelen yüksek 1s1 oynamıştır. Oltu Taşı ocaklarının tümünün bu tektonik hatta yakın ve paralel dağılıma sahip olması bu görüşü desteklemektedir (H. Yavuz Hakyemez, sözlü görüşme, 2013). Bu tektonik hattın aktivitesi en azından Pliyosen sonuna kadar sürmüştür (Konak ve diğerleri, 2001; Konak ve Hakyemez, 2001; 2008). Tektonik hatta paralel gelişen termal metamorfizma, bir kısım kömürlerin Oltu Taşı'na dönüşürken diğerlerinin neden daha düşük kalorilerde ve olağan linyit düzeyinde kaldığını açıklamaktadır.

\section{Pileki taşı}

Tip yeri: Orta ve doğu Karadeniz bölgelerinde geleneksel ekmek pişirme yönteminin uygulanmasındaki temel gereç olduğu için, Pileki taşı iyi bilinmektedir (Demir, 2010; Uzun ve Uzun, 2011; Öncel, 2013) (Şekil 1). Bununla birlikte Pileki ismi, çeşitli kaynaklarda bazen doğrudan ekmek yerine, bazen ekmeğin pişirildiği taş tepsi, bazen de taş tepsinin üretildiği ocak, taşhane için kullanılmaktadır. Pileki yaklaşık 25-35 cm çapında, 4-6 cm derinliği olan, 2-3 cm kalınlıkta, taş tepsi veya yayvan tabaktır (Şekil 6a). Bu pişirme tepsisi belli yerlerden çıkarılan özel taşlardan elle oyularak yapıldığ için "pileki taşı” denilmektedir (Şaroğlu ve diğ., 2010). Pileki oyan taş ustaları, pileki yapmak için yerinden aldıkları kayalara da "pileki taşı" adını kullanırlar.

Günümüzde Pileki veya Pileki taşı üretimi Rize civarında, belirgin olarak Rize İyidere ilçesinde yapılmaktadır. Yani, Pileki Taşı'nın tip yeri Rize İyidere'dir (Şekil 1). Buradaki bir taş ocağı çok uzun yıllardır kullanıldığı için büyükçe bir yeraltı galerisi halini almıştır (Pileki mağarası; Nazik ve diğ., 2008). Şimdilerde bu yapay mağara (367 m uzunlukta, 3-3,5 metre yükseklikte) turizme kazandırılmaya çalışılmaktadır. Mağaranın oluşturulma süresi (= pileki üretiminin başlangıcı) hakkında henüz bilimsel veri yoktur. Çeşitli internet sayfalarındaki birbirinden çok farklı söylemlerin araştırma dayanağı yoktur.

Litolojisi ve işlenme özellikleri: Pileki taşını anlatan çok sayıda internet sayfası ve yayınlanmış makale bulunmasına karşın, yalnızca iki kaynakta (Nazik ve diğ., 2008; Şaroğlu ve diğ., 2010) taşın litolojisine değinilmekte, andezitbazalt-aglomera-tüf-piroklastik topluluğu içindeki bazaltlardan üretildiği bildirilmektedir.

Pileki taşının litolojisi porfirik dokulu bazalttır. Koyu renkli hamur içinde göreceli iri feldspat kristallerinin saçılı halde olması, bu bazaltın kısmen andezit görüntüsü kazanmasına yol açmıştır. Bazaltlar çoğu yerde lav akmaları şeklinde, Pileki mağarasında ise lavlar orta ve 
küçük boyutlu yastıklar şeklindedir Pileki taşı, yastık lav olarak yerleşmiş bazalttan, çoğu kez her bir yastığın kesilmesiyle çıkarılmaktadır. Üretimin yüzlerce yıl aynı yerden yapılmasının nedeni, büyük olasılıkla, büyük yastık lav zonunun keşfedilmesi ve hep onun izlenmesi yüzündendir.

Bazalt göreceli sert bir taştır. Ocakta önce Pileki olacak bir yastık tespit edilmekte (yastık tanımı yazarlara aittir, ocakta ustalar tecrübe ile seçim yaparlar), sonra seçilen kütlenin etrafı sivri uçlu özel çekiç-kazmalarla oyulmaktadır. İki yastık sınırına kadar oyulan taş kolayca düz yüzeyli olarak çıkarılır. Bundan sonraki işlem, pileki yapımı ocak dışında sürdürülür.

Saha yayılımı ve rezerv durumu: Pileki yapımı ve kullanımı hemen hemen son bulmuştur, yalnızca turistik ve kültürel faaliyet olarak sürdürülmektedir. Bunun için gerekli taş eskiden olduğu gibi Pileki mağarasından alınmaktadır. Dolayssıyla rezerv ihtiyacı yoktur. Bununla birlikte, Pileki mağarasını içinde bulunduran Hemşindere Formasyonu'nun (Korkmaz ve Gedik, 1988) yanal devamında Pileki yapımına uygun taşlar bulunabilir. Bu konuda bir araştırma yapılmış değildir. Hemşindere Fm orta ve doğu Karadeniz bölgelerinde çok yaygındır, ihtiyaç halinde yeni yataklar bulunabilecektir.

Jeolojik özellikleri: Pileki mağarasının olduğu İyidere (Rize) civarı, Geç Kretase yaşı volkaniklastikler ile ince tabakalı denizel kireçtaşı, marn ve kumtaşlarının ardalı şekilde bulunduğu kayaçlardan oluşur. Bunlara Korkmaz ve Gedik (1988) tarafindan Hemşindere Fm adı verilmiştir. Kalınlığ1 5000 metreye yaklaşan bu birimde, hacimsel olarak, volkanik kökenli kayaçlar baskındır. Hemşindere Fm üzerine uyumlu şekilde kiltaşı-marn-kireçtaşı litolojilerinden kurulu, 325 m kalınlıktaki Geç Kretase-Paleosen yaşlı Rize Formasyonu oturmaktadir.
Hemşindere Fm'nundaki andezit, bazalt, aglomera ve tüflerin denizel tortullarla ardalanması, buradaki volkanik kütlenin denizaltı volkanizması ürünleri olduğunu, bazaltların da yastık lavlar şeklinde yerleştiğini işaret etmektedir. İyidere Pileki mağarası büyük bir yastık lav oluşumu üzerinde açılmıştır.

\section{Sille Taşı}

Tip yeri: Sille, Konya merkeze $15 \mathrm{~km}$ uzaklıkta, geçmişi antik zamanlara uzanan tarihi ve kültürel yerleşim merkezidir. Buradaki binaların yapımında yörenin kendi taşlarının kullanılmış olması dolayısıyla Sille Taşı adı doğmuştur (Şekil 1). Konya'nın pek çok tarihi yapısında da Sille Taşı kullanılmıştır. Sille'nin taş ocakları ve taş ustaları bugün iyi tanınmaktadır.

Litolojisi ve işlenme özellikleri: Sille Taş1, Göğer ve Kıral (1973)’ in “Keçimuhsine Üyesi" olarak adlandırdığı, andezit blokları ve andezitik tüflerin karışık bulunduğu "kül-blok akması" şeklinde yerleşen volkanik birim içinden üretilmektedir. Sille Taşı gerçek andezit değildir, andezitik tüftür. Gerçi, ocaklardan az oranda çıkan gerçek andezit blokları da aynı isimle pazarlanır, ancak bunlar göreceli işlenme zorluğu nedeniyle fazla tercih edilmezler. Bunlara yöresel ad ile "Kentaşı" adı verilir (ken = taş ocağı).

Sille Taş1, tüflerden düşük, andezitlerden yüksek gözenekliğe sahiptir, bu nedenle göreceli kolay işlenir. Kapiler su emme katsayısı 2,6 - 2,9 $\mathrm{kg} / \mathrm{m}^{2}$.h olarak tespit edilmiştir (Özdemir, 2002). $\mathrm{Bu}$ değer kireçtaşlarına göre yüksek olmakla beraber, iyi kaliteli betonun su emme katsayısından çok düşüktür. Bu nedenle yapıtaşı ve kaplamataşı olarak eskiden beri güvenle kullanılmaktadır. Isı dayanımı isteyen yerlerde de tercih edilen bir taştır. 
Saha yayılımı ve rezerv durumu: Taş üretiminin yapıldığı ocaklar Sille civarındadır. Öte yandan, Sille Taşı'nı bulunduran birimin az bir kısmı Sille çevresinde yüzeyler. Konya ile Beyşehir-Seydişehir çöküntülerini ayıran Erenler Dağı'nın doğu ve batı eteklerinde, aynı andezitik blok-kül akmalarına yaygın olarak rastlanır (MTA, 2002c). Özetle, Sille Taşı için rezerv sorunu yoktur. Sorun hizla genişleyen yerleşim yerleri nedeniyle taş ocaklarının şehir yakınında veya içinde kalmasıdır.

\section{Jeolojik özellikleri: Sille Taşı'nı} bulunduran Keçimuhsine Üyesi Geç MiyosenPliyosen yaşlıdır (Hakyemez ve diğ., 1992; MTA, 2002c). Bu birim sahada kaba kırıntılı tortul kayaçlarla ardalanmalı ve yanal geçişli olarak görülür. Hata bazı yerlerde alüvyon yelpazesi tortullarının volkanitlerle bölündüğü yerler vardır. Bazı yerlerde ise andezit lav akmalarının egemenliği dikkat çeker. Volkanik çıkış merkezleri piroklastik örtü nedeniyle ayırt edilemez, ama Erenler Dağı'nın birden çok noktasından püskürerek çevreye yayılmış izlenimi sunmaktadırlar.

\section{Traverten ve mermer}

Traverten ve mermerler ülkemizdeki doğal taş sektörünün neredeyse bütününü oluştururlar. Özellikle ihraç edilen ürünlerin tamamı bunlardan ibarettir. Traverten ve mermerlerin bu makale kapsamında tatmin edici şekilde açıklanması mümkün değildir; konu bütünlüğü sağlamak için buraya alınmıştır.

Doğal taş sektöründe blok veren, parlatılabilen, parladıktan sonra çekici yüzey görüntüsü olan bütün taşlar (magmatik, metamorfik, tortul kayaçlar) "mermer" olarak nitelendirilir (TR_ME, 2012; TSE, 2012). Gerçek mermer ise kireçtaşlarının ve dolomitlerin 1s1, basınç veya her ikisinin ortak tesiriyle başkalaşıma uğramış metamorfik kayaçtır. Anadolu'nun değişik yörelerinde üstün kaliteli gerçek mermerler üretilmektedir; Afyon somakisi, Kemalpaşa beyazı, Elazı̆̆ vişnesi gibi (Şekil 1). Bir bakıma Anadolu mermer ülkesidir. Hatta Roma ve Erken Bizans dönemlerinde, imparatorlukların önemli yapılarında kullanılan taşlar Marmara Adası'ndaki ocaklardan sökülüp götürüldüğü için, adanın adından taşın ismi üretilmiştir (bkz. Meydan Larousse, Mermer maddesi, Meydan Yayınevi, 1969, İstanbul). Ticari mermer son y1llarda taş yontucularının kullanımıyla yaygınlaşan bir terimdir.

Ticari anlamda dört tip mermer tanımlanır. Bunlar;

1. Gerçek mermerler; metamorfik kalsit kristallerinden oluşan, yoğunluğu 2,7-3 g/ $\mathrm{cm}^{3}$ arasında değişen doğal taşlardır. Antik ve tarihi yapılardaki sütunlar, sütun başları, heykeller, kabartmalar ve lahitlerin çok büyük bölümü bu taşlardan (gerçek mermer) yapılmıştır. Dayanıklığı ve parlak görüntüsü ile en çok tercih edilen yontu taşıdır. Bütün Ortadoğu ülkelerindeki önemli yapıların mermerleri ya hazırlanmış ya da blok taş olarak Anadolu'dan götürülmüştür. Mermerlerin rengi içindeki kalıntıların eseridir. Organik madde siyah, demir varlığı sarı ve kırmızı renkleri üretir. Desenler ise kireçtaşı veya dolomit anakayanın dokusuna, metamorfizma türü ve derecesine, örneğin kalsitlerin yeniden kristallenmesine, stilolit oluşumuna vb bağlıdır.

2. Kireçtaşı mermerleri; olağan kireçtaşı ve dolomitlerin blok veren türleridir. Kimyasal bileşimin \% 90 kadarı karbonat, kalanı Fe, Mg, Ti, Al oksitler olabilir. Türkiye'nin bütün yörelerinde bulunur. Jeolojik olarak daha yaşlı olanları daha iyi ürünler verirler. Örneğin Permiyen kireçtaşı mermeri, Paleosen mermerine tercih edilir. Çoğunlukla kesme yapıtaşı olarak kullanılırlar. 
Son y1llardaki gelişen işleme teknolojisi yardımıyla, gerçek mermerlerin kullanıldığı bütün uygulamalarda yer alırlar. $\mathrm{Bu}$ nedenle ülkenin hemen her yöresinde kireçtaşı mermeri (?!) üreten taş ocakları hızla yayılmaktadır.

\section{Traverten mermerleri: Ekserisi} Kuvaterner yaşlı olan travertenler ülkemizin hemen her yerinde bulunan oluşuklardır. Kireçtaş1 temeli kesen fay zonları boyunca bolca gözlenirler. Kendine has oluşum türleri, dokuları ve yaygın bulunuşları ile Denizli travertenleri ve Antalya travertenleri bütün dünyada tanınmaktadır. Travertenlerin ticarileşmesi son yıllarda gerçekleşmiştir. Bu kayaçlardaki gözenekliliğin yüksek oluşu yapıtaşı olarak kullanımını uzun süre engellemiştir. Ancak gelişen teknoloji kesilen traverten yüzeylerindeki boşlukların doldurulmasını ve parlatılmasını sağlamış, sonrasında ülkemizdeki travertenlerin pazara çıkmasına fırsat vermiştir. Artık travertenler her iklim şartında ve her alanda güvenle kullanılan taştır. İşlenme kolaylığ 1 ve öteki doğal taşlara oranla hafifoluşu (ortalama birim hacim ağırlığ 12,3 $\mathrm{g} / \mathrm{cm}^{3}$ ) pazar payını artırmaktadır. En çok kaplama taşı olarak kullanılır. Gözenek doldurulması nedeniyle travertenler blok olarak değil, işlenmiş (kesilmiş, gözenekleri doldurulmuş, parlatılmış), siparişe göre istenen boyutlarda ihraç edilmektedir. $\mathrm{Bu}$ konuda Denizli traverten işletmeleri öncü konumdadır (Özkul ve diğ., 2002).

Travertenler hakkında bir gelişme, artık bunların aktif fayları, dolayısıyla sismik bakımdan aktif zonları işaret ettiklerinin anlaşılmasıdır. Tersinden bakışla, ülkemizdeki traverten zenginliğinin nedenlerinden birisi faylarla birlikte gözlenmesidir. Ayrıca, yakın zamana kadar travertenlerde fosil oluşamayacağı kanaati hâkimken, son y1llarda bolca karasal fosiller (tatlı su istakozları, y1lan iskeleti, boynuz, memeli kemikleri, hominid kalıntıları vb) bulunmuş, böylece travertenlerin ekonomik değerleri yanında bilimsel önemleri de hızla artmıştır (Kappelman ve diğ., 2008) (Şekil 6d).

4. Magmatik kökenli mermerler: Bu gruba granit, siyenit, diyorit gibi parlatılabilen kristalli magmatik kayaçlar girer. Bunların kapsadığı fazla miktar kuvars nedeniyle işlenmeleri güçtür. Ayrıca taşları blok halinde çıkarmak kolay değildir. Diğer ticari mermerlere göre fiyatları çok yüksektir, bu nedenle kullanımı sınırlıdır. Ülkemizde üretimi azdır. Daha çok Güney Afrika ve Avustralya'dan blok olarak ithal edilir. Son y1llarda ise Çin'den işlenmiş olarak satın alınmaktadır.

Daha önce belirtildiği gibi, doğal taş olarak traverten ve mermerler büyük bir gruptur. Ayrı olarak ele alınması ve jeomiras açısından özel olarak irdelenmeleri gerekir. Bu taşların dünyadaki değerlerini kazanması için öncelikle satıldıkları ülkelerdeki kullanım yerlerinin kayıtlarının tutulması, tüketim dökümlerinin çıkarılması, antik ve tarihi yapılardaki mermerlerin hangi kaynaklardan ve ocaklardan üretildiklerinin saptanması gerekmektedir. Özetle, geçmişteki durumun ortaya konulması, günümüz için de iyi bir kayıt sistemi kurulması çok yararlı olacaktır. Bu, vergilendirme veya üretim sinırlaması amacıyla değil, Anadolu mermer ve travertenlerinin kültürel değerlerini koruma ve gelecek nesillere aktarma sorumluluğunu yerine getirmek için gereklidir. 


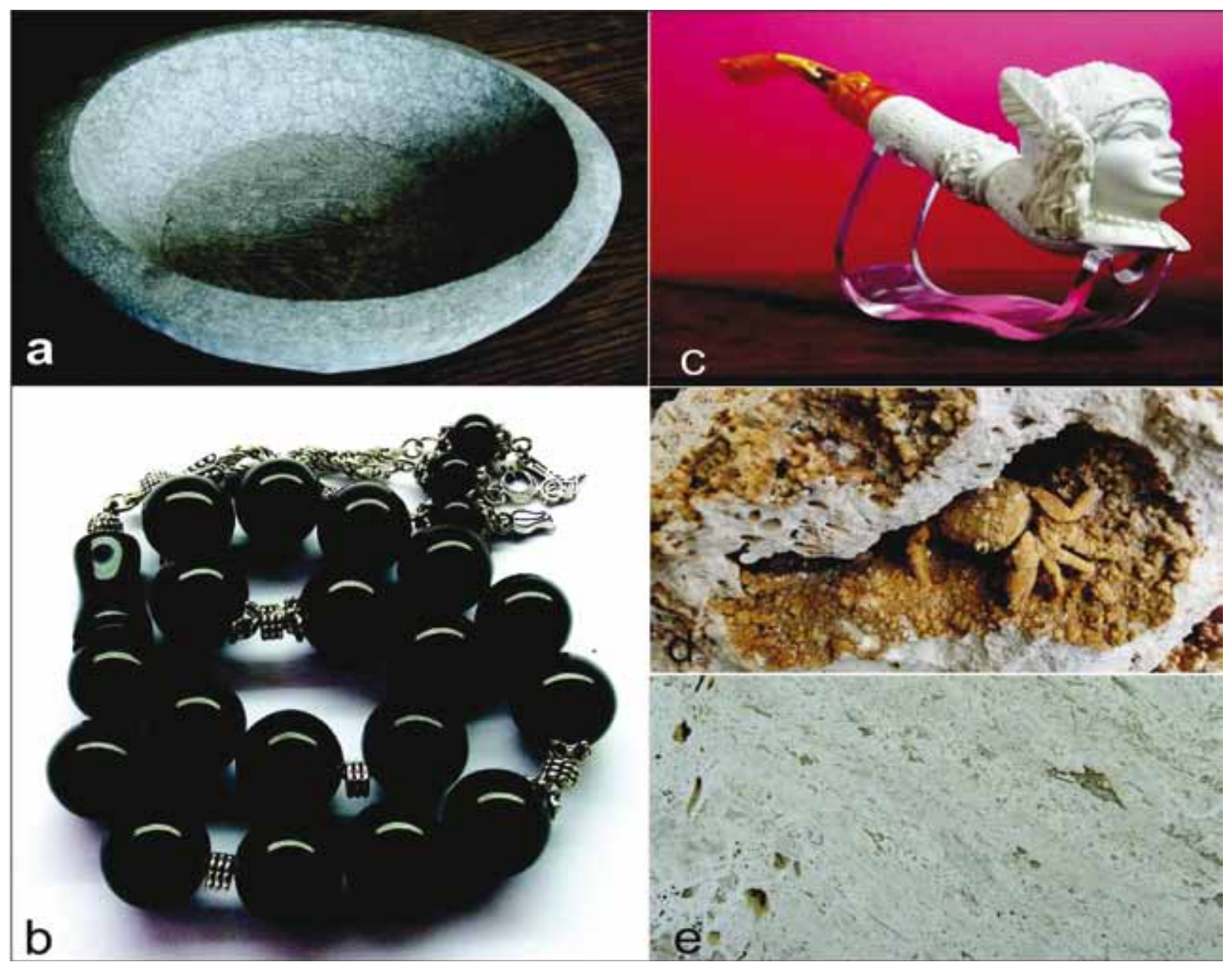

Şekil 6. Doğal taşlardan üretilmiş değişik ürünler; a. Pileki (Şaroğlu vd 2010'dan), b. Oltu Taşı tespih (oltutasi. com'dan), c. Lületaşından sigara ağızlığı (eskisehirinhaberi.com'dan), d. Denizli Kaklık travertenlerinde yengeç fosili, e. Tipik traverten ve bol gözenekli dokusu.

Figure 6. Handcrafts produced by using natural Stones; a. Pileki (after Şaroğlu et al., 2010), b. Rosary made of Oltu Stone (from oltutasi.com), c. Pipo produced from meerschaum (from eskisehrinhaberi.com), d. Crab fossil within Denizli Kakllk travertines, e. Typical porous texture of a travertine.

\section{TARTIŞMA VE SONUÇLAR}

Jeolojik yap1 ile birlikte Anadolu'nun zengin kültürel geçmişi, dayanıklı ve dekoratif doğal taşların bolca kullanılmasına ve kalıcı eserlerin ortaya çıkmasına olanak vermiştir. Günümüze gelen böyle pek çok antik ve tarihi yapı büyük hayranlıkla ziyaret edilmektedir. Aynı taşların çoğu bugün de kullanılmaktadır; ancak bunların kamuoyu tarafından değerlerinin ve oluşumlarının fazlaca tanındığı söylenemez. Bunun en iyi örneği internet ortamındaki eksik ve yanlış bilgilerdir. Değinilen belgelerde görüleceği üzere, şimdiye kadar doğal taşlar büyük ölçüde kültür ve folklor araştırmacıları tarafından ele alınmıştır. Bunlardaki jeolojik bilgiler zorunlu olarak aktarma yoluyla, eksik veya yanlış olarak verilme durumundadır. Bu durum taşların olduğu bölgedeki jeolojik inceleme azlığından değil, 
bakış açısı farklılığında kaynaklanmaktadır. Örneğin, Erzurum yöresini çeşitli yönleriyle ele alan çok sayıda jeoloji çalışması bulunmaktadır ve bunlarda "Oltu Taşı" ismi hemen hemen yalnızca kömür konulu incelemelerde vardır ve üzerinde durulmadan geçilmektedir. Diğer yöreler için de durum aynıdır. Bu bir saptamadır, başka amacı yoktur ve önemli jeomiras değerlerimiz konusundaki araştırma gereğini işaret etmektedir. Bu yazı ile bazı çok tanınan doğal taşlar hakkında bilimsel bilgi verilmeye çalışılmıştır. Öte yandan, incelenen doğal taşların bulunduğu bölgelerdeki jeolojik araştırmaların yalnızca konu ile doğrudan ilişkili olanlarına değinme zorunluluğu olmuştur. Tersi durumda yazı jeoloji bibliyografyasına dönüşebilirdi.

Türkiye, jeolojik yapısı dolayısıyla, doğal taşların yanında yarı kıymetli taşlar ve süstaşları bakımından da zengin sayılır. Büyük bölümü ithal yolla gelse de bütün şehirlerde bazı doğal taşlar ile süstaşlarının yaygın şekilde pazarlandığı görülür. Bu pazarda işlenebilen bütün mineraller müşteri bulabilmektedir. Eldeki yazı kapsamında ise yalnızca yaygın bulunan, adeta Türkiye ile özdeşleşmiş olanlara yer verilmiştir. Bununla birlikte yapılan ayırımın ne derece yerinde olduğu tartışmalıdır. İncelemeler çoğaldıkça daha iyi ölçütlerin ortaya çıkacağı düşünülmektedir.

Doğal taşlar konusundaki terminoloji gün geçtikçe karmaşık hale gelmektedir. İlginçtir ki, terim ve tanımların çoğunluğu yerbilimci olmayanlar ve özellikle son yıllarda pazarlamacılar tarafından uydurulmaktadır. Örneğin stres taşı, uyku taşı, nazar taşı gibi. Ayrıca, mermer tanımı da büyük bir karmaşa içermektedir. Türkçe literatürde ve standartlarda olsa bile, kendine has bir kayaç olan "mermer" in "ticari taş" veya "doğal taş” karşılığı kullanılması kolay benimsenecek bir durum değildir. Ülkemizde doğal taş ve yerbilimi kültürünün yaygınlaşması için her taşın kendi adıyla ticarileşmesi gerekir. Bu konuda yerbilimcilere sorumluluk düştüğü kanaatindeyiz.

Ülkenin hemen her tarafinda tanınan ve ayrı bir taş olmaktan çok adeta yapıtaşları için "nitelik" anlatan doğal taşlar da vardır. Bunların kendileri ve çıkarıldıkları ocaklar ticari bakımdan yüksek değerlerdedir. Ancak onlar bu yazı kapsamına alınmamıştır. Örneğin "Küfeki taşı", "kayrak taşı" gibi (Arığlu ve Arıoğlu, 1993; Özpınar ve diğ., 1999). Piyasada aranan taşlar olmalarına karşın jeomiras değerleri ileri derecede değildir.

$\mathrm{Bu}$ yazı kapsamının dışında olmakla beraber değinilmesi gereken husus, jeomiras nitelikli doğal taşların tarihsel dönemlerde işletildikleri ocakların da başlı başına kültürel jeoloji açısından zenginlik olduğu ve mutlaka korunmaları için ele alınmaları gerektiğidir. Bunun en iyi iki örneği Iğdır Tuzluca'daki tuz mağarası ile Çankırı'daki tuz mağarasıdır. Bunun gibi yapay mağaralar, tarihsel ocaklar, eski maden atıkları, tarihi maden galerileri önemli araştırma konuları, jeoturizm araçları ve şüphesiz kültürel jeolojinin vazgeçilmez malzemeleridir. $\mathrm{Bu}$ konuların daha geniş şekilde ele alındığı araştırmalar yerbilimlerinin ve kültürümüzün zenginleşmesine katkı sağlayacaktır.

\section{KATKI BELIRTME}

Bu çalışmanın çeşitli aşamalarında Yaşar Suludere ve Dr. Fuat Şaroğlu, yöresel ve bölgesel jeoloji hakkında bilgi, belge ve görüşlerini paylaşarak katkı vermişlerdir. Ayrıca F. Şaroğlu, yerine gitmeden önce orijinal Pileki temin etmiş ve doğrudan incelememizi sağlamıştır. Saha incelemeleri sirasında Prof. Dr. Ercan Aksoy (Eren Üniv. Mühendislik Fak. Dekanı), Bitlis, Şanlıurfa ve Eskişehir İl Kültür ve Turizm Müdürlüğü yetkilileri, Sille incelemeleri için Alper Erkan 
destek sağlamışlar ve ilgi göstermişlerdir. Oltu Taşı'nın tanımlanmasında, dergi hakemi Dr. H. Yavuz Hakyemez verilen jeoloji açıklamalarının eksiklik ve hatalarını gidermiş, ulaşamadığımız kaynakları temin etmiştir. Dergi editörü değişik aşamalarda teşvik edici katkıda bulunmuştur. Yazarlar, adı geçenlere katkıları için şükranlarını sunarlar.

\section{EXTENDED SUMMARY}

Natural Stones, the sources of geological knowledge, have been also basic elements of all kinds of social development and culture, even not for the life itself. To be able to differ the significance of the natural stones in the human life, it is enough simply seeing the hand tools of early humans, caves used as settlements, Göbekli Tepe in souteastern Anatolia, Egyptian pyramids, AyaSofia, Selimiye Mosque in Edirne, Kaşıkçı Diamond or Ephesus ruins, and/or ornament materials in museums. However, natural stones are mainly represented by building stones generally as impressive and large monuments in everywhere have been constructed by blocks of such stones. Presently, consuming of natural stones, particularly in Turkey, is increasing, because they are not only decorative but also resistant to weathering and thermal conditions. Consequently, natural stones are unique part of the architectural history and they have been preferred and used in all civilisations all times (Farelly, 2011). On the other hand, sources of the natural stones are not endless and its wild consume seems to be causes of new problems i.e for ground waters, geological heritage and natural environments in close future. Moreover, natural stones are geological heritage of Turkey, but only only few earthscientists are aware of threats from geoconservation point of view. The lack of reliable information about them is another problem. So, Ahlat Stone, Ankara Stone,
Lületaşı, Midyat Stone, Nevşehir Stone, Oltu Stone, Pileki Stone and Sille Stone are subject of this study. They are also significant geosites of Turkey, thus it is possible to describe them as "national stones". Their names are mostly due to the local geography where they were found or exposed (Fig. 1). The aim of this paper is to introduce cited natural stones, emphasizing geological properties together with their geoestatic and geoheritage values. In addition, these stones are key elements of cultural geology in the country as they have been used some monuments i.e. Seljuks' tombs stels (by Ahlat Stone), Mardin houses (by Midyat Stone), monasteries (by Sille Stone Ankara Stone, Midyat Stone), Mosolé dAtaturk (by travertine and marble) and and well-known artifacts i.e. tobacco pipe, bracelet, collier (by lületaşı and Oltu Stone). Some brief explanations about them are as follows.

Ahlat Stone is a kind of porous, ironbearing ignimbrite formed by the Nemrut volcano of Quaternary during the early phase of its eruption period. Red coloured of Ahlat Stone is attractive and they are used together with gray one. All houses and monuments in Bitlis, Ahlat, Adilcevaz and Van regions had been built or covere by Ahlat Stone, preferably red coloured one since the Seljuks time.

Ankara Stone is an andesite with high volume of plagioglase, mostly pink in colur. The stone is dense and compact. Mostly it is used outside as it is resitant to atmospheric conditions. They were formed by individual explosions in Ankara region during the Miocene time.

Lületaşı (Eskişehir Stone) is a white claystone composed of alpha-spepiolite. It is bedded within conglomerate nodular structure. It is mining by individuals using deep and narrow tunnels. Trade of its as raw material is forbidden. 
Midyat Stone is a gray limestone of Eocene deposited on the shelf of Arabian continent; so the formation covers large areas in the souteastern Turkey. Its exposures have been mapped as Midyat Formation and Hoya Fm in somewhere.

Nevşehir Stone is a porous, fine grained ignimbrite of Cappadocian Volcanic Province occured during the late Neogene and Quaternary. It is genarally white and yellowish white in colour. It is not convenient for outside usage.

Oltu Stone is a kind of compact coal or phytolite found within the fine-grained clastic deposits of Mesozoic as 1-2 cm of nodules. Its hardness is aroud 2 in scale of Mohs. Most probably it occured by thermal activity of Palaeogene volcanism on coal after its primary deposition.

Pileki Stone is a porfiri basalt in origin. It is produced from pillow lavas of Mesozoic by individuals using caves. Pileki itself is a rock plate for bread preparation locally.

Sille Stone which uses widely in ovens as resistant is an andesite of Late Miocene-Pliocene in age.

Travertine ve marble are very widespread rocks in Turkey based on geological features of the country. Presently, they are the most prominent export material of the country, creating some environmental problems.

\section{DEĞİNILLEN BELGELER}

Adin, H., 2007. Mardin ve Midyat'ta kullanılan bina yapı taşlarının bazı fiziksel özellikleri. Mühendis ve Makine 48 (570), 13-17.

Alpaslan, E., 2010. Oltu Taşı, altın ve gümüş kullanılarak üretilen kol düğmesi ve kravat iğnesi örneklerinin incelenmesi. Zeitschrift für die Welt der Türken (Journal of World of Turks) 2, 179-189.

Altunel, E., 2012. Kültürel Jeoloji; jeolojinin insanoğlunun yaşamı üzerindeki etkileri. $\dot{I}_{c ̧}$. Kuvaterner Bilimi (ed. N.Kazancı,
A. Gürbüz), Ankara Üniv. Yayını no 350, Ankara, $195-$ 214.

Arıŏlu, N. ve Arığlu, E.,1993. Mimar Sinan'ın seçtiği taş; küfeki taşı ve çekme dayanımı. http://www.e-kutuphane.imo. org.tr/pdf/12690. s. 1021-1034.

Atay, F.R., 1968. Çankaya. Pozitif Yayınları, 12. baskı, 651 s., İstanbul.

Aydar, E., Schmitt, A.K., Çubukçu, H.E., Akın, L., Ersoy, O., Şen, E., Duncan, R.A., Atıc1, G., 2012. Correlation of ignimbrites in the central Anatolian volcanic province using zircon and plagioclase ages and zircon compositions. Journal of Volcanology and Geothermal Research 213-214, 83-97.

BGS, 2011. Strategic stone study; building stone atlases of 32 counties. English Heritage, British Geological Survey, England.

Bilim, C., 1997. Deniz köpüğü; lületaşı. OTAM, Ankara Üniversitesi Osmanlı Tarihi Araştırma ve Uygulama Merkezi Dergisi $8,117-127$.

Bozkurt, R., 1989. Lületaşı sorunları ve çözüm önerileri. Anadolu Üniversitesi İktisadi ve İdari Bilimler Fakültesi Dergisi 7, 193-204.

Bozkuş, C., 1990. Oltu-Narman Tersiyer havzası kuzeydoğusunun (Kömürlü) stratigrafisi. Türkiye Jeoloji Bülteni 33, 47-55.

Büyükbağış, İ.S., 2012. 'Doğaltaşlar İsimlendirme Kriterleri' standardının (TS-EN-12440/2008) ülkemize getirdikleri. TSE Standard Dergisi 606, 44-47.

Demir, E.,2012. Doğu Karadeniz bölgesindeki pileki/bileki. www. necatidemir.net/images/demir/bkosem/bileki_pileki.pdf'

Dinçer, İ., Özvan, A., Akın,M., Tapan, M., Oyan, V., 2012. İgnimbiritlerin kapiler su emme potansiyellerinin değerlendirilmesi; Ahlat taşı örneği. Yüzüncü Y1 Üniversitesi Fen Bilimleri Enstitüsü Dergisi 17/2, 64-71.

Doğanay, H., 1997. Fitolojik kökenli bir fosil; Oltu taşı. Doğu Coğrafya Dergisi 3/2, 2-22.

DYDTS (Doğal Yaşam Doğal Taş Sempozyumu), 2012. Bildiri Kitabı. 29 - 30 Mart 2012 MSGSÜ Sedad Hakkı Eldem Oditoryumu, 187 s., Fındıklı / İstanbul.

EGS, 2011. EuroGeoSurveys annual report., The geological surveys of Europe, 126 s., Paris.

Ercan, T., 1986. Orta Anadolu'daki Senozoyik volkanizması. Maden Tetkik ve Arama Dergisi 107, 119-140.

Erdal, M. ve Şimşek, O., 2011. Ahlat taşı (ignimbrit) atıklarının taşunu olarak beton içinde kullanılabilirliğinin araştırılması. Politeknik Dergisi 14/3, 173-177.

Farrelly, L., 2011. Mimarlığın Temelleri (Çev. Neslihan Şık). Literatür Yayınları, Akademik Temeller Dizisi 01, İstanbul. 
Gevrek, A.İ., 1997. Aksaray doğusu, Ihlara-Derinkuyu yöresindeki volkanoklastiklerin sedimantolojisi. Doktora Tezi, Ankara Üniv Fen Bil. Enst., Ankara, 230 s. (yayınlanmamış).

Gevrek, A.I. ve Kazanc1, N., 2000, A Pleistocene pyroclastic-poor maar from central Anatolia,Turkey; the possible tectonic interaction on a phreatic explosion. Journal of Vocanology and Geothermal Research 95, 309 - 317.

Göğer, E. ve Kıral, K., 1973. Kızılören Dolayının (Konya Batıs1) Genel Stratigrafisi. Maden Tetkik ve Arama Genel Müdürlüğü, Rapor No 5204, Ankara (yayınlanmamış).

Gökaltun, E., 2004. Atmosferik gaz ve asitlerin doğal taş yapı malzemeleri üzerindeki etkilerinin deneysel yöntemler ile analizi. Mimarlar Odası İstanbul Büyükkent Şubesi 2. Ulusal Yapı Malzemesi Kongresi ve Sergisi bildiriler kitabı, İstanbul, s. 149-160.

Gökaltun, E., 2011. The changes in the structre of limestones as a result of calcium sulfate (gypsum stone) formation caused by atmospheric polluters. World Applied Sciences Journal 13, 2082-2088.

Gül, A.O., Çağlar, M.D., Serttaş, U., Gedik, N., Engün, H., Ürersoy, T., Banger, G., 2010. Lületaşı. Eskişehir Valiliği İl Kültür ve Turizm Müdürlüğü, Yayın No: 14, Eskişehir, 32 s.

Hakyemez, Y., Elibol, E., Umut, M., Bakırhan, B., Kara, İ., Dağıstan, H., Metin, T., Erdoğan, N., 1992. KonyaÇumra-Akören dolayının jeolojisi. Maden Tetkik ve Arama Genel Müdürlüğü, Rapor No 9449, 73s, Ankara (yayınlanmamış).

Hatipoğlu, M., Ajo, D., Kibici, Y., Passeri, D., 2012. Natural carbon black (Oltu-stone) from Turkey: a micro-Raman study. Neues Jb. Mineral. Abh. 189 (1), 97-101.

Heldal, T. ve Neeb, P. R. 2000: Natural stone in Norway; production, deposits and developments. Norges Geologiske Undersøkelse Bulletin 436, 15-26.

Kappelman, J., Alçiçek, M.C., Kazancı, N., Schultz, M.,, Özkul, M., Şen, Ş., 2008. The first homo erectus from Turkey and implications for migrations into temparate Eurasia. American Journal of Physical Anthropology 135, 110116.

Karaoğlu, Ö., Özdemir, Y., Tolluoğlu, Ü., Karabıyıkoğlu, M., Köse, O., Froger,J.L., 2005. Stratigraphy of the volcanic products around Nemrut caldera; implications for reconstruction of the caldera formation. Turkish Journal of Earth Sciences 14, 123-143.

Karayiğit, A.İ., 2007. Origin and properties of Oltu gemstone coal. Energy Sources 29, 1279-1284

Kaya, A.C., 2008. Midyat Taşının Kaplama ve Yapıda Kullanılabilirliğinin Araştırılması. Yüksek Lisans Tezi, Ç. Ü. Fen Bil. Enst. Maden Müh. Anabilim Dalı, 93 s., Adana (yayınlanmamış).
Kazanc1, N., 2005. Kültürel Jeoloji. Mavi Gezegen 12, 4-5.

Kazanc1, N., 2010. Jeolojik Koruma; Kavram ve Terimler. Jeolojik Mirası Koruma Derneği yayını, 60 s., Ankara

Kazanc1, N. ve Gevrek, A.İ., 1996. Nevşehir-Acıgöl maarının tortul dolgusu (Kuvaterner, İç Anadolu); jeotermal süreçlerin fasiyes gelişimine etkileri. Türkiye Jeoloji Bülteni 39, $27-44$.

Kazanc1, N., Gevrek, A.İ., Varol, B., 1995. Facies changes and high calorific peat formations in a Quaternary maar lake of central Anatolia, Turkey; the possible role of geothermal processes in a closed lacustrine basin. Sedimentary Geology 94, 255 - 266.

Kazanc1, N. ve Şaroğlu, F., 2009. Türkiye Jeositleri Çatı Listesi. 62. Türkiye Jeoloji Kurultayı (13-17 Nisan 2009) Bildiri Özleri Kitabı-I, Jeoloji Mühendisleri Odası, Ankara, s. 266-267.

Koçyiğit, A., Winchester, J.A., Bozkurt, E., Holland, G., Beyhan, A., 2003. Saraçkoy volcanic suite; implications for the subductional phase of arc evolution in the Galatean arc complex, Ankara, Turkey. Geological Journal 38, 1-14.

Konak, N. ve Hakyemez, H.Y., 2001, Tectonic units of the easternmost part of the Pontides: Stratigraphical and structural implications. Proceedings of the $2^{\text {nd }}$ Int. Symp. on the Petroleum Geology and Hydrocarbon Potential of the Black Sea Area, 93-103, 22-24 September 1996, Şile-İstanbul-Turkey, Turkish Association of Petroleum Geologists, Spec. Publ. 4, 93-103.

Konak, N., Hakyemez, H.Y., Bilgiç, T., Bilgin, Z.R., Hepşen, N., Ercan, T., 2001. Kuzeydoğu Pontidlerin (Oltu-OlurŞenkaya-Narman-Tortum-Uzundere-Yusufeli) Jeolojisi Maden Tetkik ve Arama Genel Müdürlüğü Raporu, no: 10489, Ankara.

Konak, N. ve Hakyemez, H. Y., 2008. 1:100.000 Ölçekli Türkiye Jeoloji Haritaları, Tortum-G48 Paftası. No: 104, Maden Tetkik ve Arama Genel Müdürlüğü Jeoloji Etütleri Dairesi, 69 s., Ankara.

Konak, N. ve Hakyemez, H. Y., 2009. 1:100.000 Ölçekli Türkiye Jeoloji Haritaları, Tortum-G47Paftası. No: 105, Maden Tetkik ve Arama Genel Müdürlüğü Jeoloji Etütleri Dairesi, 72 s., Ankara.

Korkanç, M., 2007. İgnimbritlerin jeomekanik özelliklerinin yapı taşı olarak kullanımına etkisi; Nevşehir Taşı. Jeoloji Mühendisliği Dergisi 31, 49-60.

Korkmaz, S. ve Gedik, A., 1988. Rize-Fındıklı-Çamlıhemşin arasında kalan bölgenin jeolojisi ve petrol oluşumları. Jeoloji Mühendisliği 32-33, 5-15.

MTA, 2002a. 1/500 000 Ölçekli Türkiye Jeoloji Haritası Ankara Paftası. Maden Tetkik ve Arama Genel Müdürlüğü, Ankara. 
MTA, 2002b. 1/500 000 Ölçekli Türkiye Jeoloji Haritası Diyarbakır Paftası. Maden Tetkik ve Arama Genel Müdürlüğü, Ankara.

MTA, 2002c. 1/500 000 Ölçekli Türkiye Jeoloji Haritası Konya Paftası. Maden Tetkik ve Arama Genel Müdürlüğü, Ankara.

Mutlu, S., 2005. Türkiye'nin doğal taşlarının yörelerine göre dağılımı. Stone Yapı Endüstri Merkezi, Yapı Yayın 1, 43-63.

Nairn, A.E.M. ve Alsharhan, A.S., 1997. Sedimentary Basins and Petroleum Geology of the Middle East. Elsevier Pub., Amsterdam.

Nazik, L., Savaş, F., Kahraman, İ., Acar, C., 2008. Pileki Mağarası (Taşhane) İyidere- Rize araştırma raporu. Maden Tetkik ve Arama Genel Müdürlüğü, Rapor no 11012, Ankara (yayınlanmamış).

Ocakoğlu, F., 2007. A re-evaluation of the Eskisşehir Fault Zone as a recent extensional structure in NW Turkey. Journal of Asian Earth Sciences 31, 91-103.

Öncel, Ü., 2013. Ekmeğimizi pişirdiğimiz bir araç; pileki. Bizim Ahıska Kış 2013, 47-48.

Önenç, D.İ., Kıral, N., Erkanol, D., Tulukçu, A., 2006. Medeniyetlerin Taşı "Mardin Taşı" ve Özellikleri. 59. Türkiye jeoloji Kurultayı (20-24 Mart 2006) Bildiri Özleri Kitabı, Jeoloji Mühendisleri Odası, Ankara, 469-471.

Özdemir, A., 2002. Bazı yap1 malzemelerin kapiler su emme potansiyelleri. Jeoloji Mühendisliği 26, 19-32.

Özkaya, İ., 1974. Güneydoğu Anadolu Sason ve Baykan yöresinin stratigrafisi. Türkiye Jeoloji Kurumu Bülteni 17, 51-72.

Özkul, M., Varol, B., Alcicek, M.C., 2002. Denizli tarvertenlerinin petrografisi ve depolanma ortamları. Maden Tetkik ve Arama Dergisi 125, 13-29.

Özpınar, Y., Bozkurt, R., Çobanoğlu, İ., Küçük, B., 1999. Uşak ve Sandıklı civarındaki "küfeki taşlarının (aglomera ve tüf) petrografik ve petrokimyasal incelenmesi, bunların yapıtaşı ve agrega olarak değerlendirilmesi. 2.Ulusal Kırmataş Sempozyumu'99 Bildiriler Kitabı, İstanbul, 99-111.

Perinçek, D., Duran, O., Bozdoğan, N., ve Çoruh, T., 1992. Güneydoğu Türkiye'de otokton sedimanter kayaların stratigrafisi ve paleocoğrafik evrimi: Türkiye ve çevresinin tektoniği, petrol potansiyeli. Ozan Sungurlu Sempozyumu Bildirileri, 274-305.

Petrascheck, W.E., 1963. Eskişehir civarındaki lületaşı yatakları. Maden Tetkik ve Arama Dergisi 61, 10-13.

Pivko, D.,2003. Natural stones in earth's history. Acta Geologica 58, 73-86.
Sabah, E. ve Çelik, M.S., 1999. Sepiyolit; özellikleri ve kullanım alanları. 3.Endüstriyel Hammaddeler Sempozyumu (14-J 5 Ekim 1999, Izmir) Bildiriler Kitabı, 132-146.

Sert, M., 2010. Isparta ve Nevşehir yöresi volkanik kökenli taşların fiziko-mekanik özelliklerinin belirlenerek kullanım alanlarının irdelenmesi. Yüksek lisans tezi, SDÜ Fen Bilimleri Enstitüsü, $92 \mathrm{~s}$, Isparta (yayınlanmamış).

Seyitoğlu, G. ve Büyükönal, G., 1995. Geochemistry of Ankara volcanics and the implications of their K-Ar dates on the Cenozoic stratigraphy of central Turkey. Turkish Journal of Earth Sciences, 4, 87-92.

Sungurlu, O., 1972. VI. Bölge Gölbaşı - Gerger arasındaki sahanın jeolojisi. TPAO Rap. No: 802, Ankara (yayınlanmamış).

Şahin, K., Yılmaz, A., Günel, A., 2013. Midyat taşı ve taş işçiliği; doğal ve kültürel çevre ilişkileri. Uluslararası Sosyal Araştırmalar Dergisi 6, 315-326.

Şaroğlu, F., Güner, Y., Nazik, L., Aksoy, B., 2010. Pileki mağarası ve jeokültürel değeri. 1. Uluslararası Jeolojik Koruma Sempozyumu ve Güneydoğu Avrupa Ülkeleri ProGEO Toplantısı (15-19 Eylül 2010, Fırat Üniversitesi, Elazığ) Bildiri Özetleri, s. 34-35.

Şengüler, İ., ve Izladı, E., 2013. Eskişehir grabeninin neojen stratigrafisi ve sismik yansıma etüdü ile kömür çökelim alanının araştırılması. MTA Dergisi 146, 105-116.

Şimşek, O. ve Erdal, M., 2004. Ahlat Taşının (ignimbrit) bazı mekanik ve fiziksel özelliklerinin araştırılması. Gazi Ü. Fen Bilimleri Dergisi 17 (4), 71-78.

Tankut, A., Akıman, O., Türkmenoğlu, A., Güleç, N., Göker, T., 1990. Tertiary volcanic rocks in northwest central Anatolia, Turkey. In: Savaşçı, M.Y., Eronat, A.H. (eds), IESCA 1990 Proceedings vol. II, 450-466.

Taşlıgil, N. ve Güven, Ş., 2011. Doğal ve kültürel özellikleri ile lületaşı. Uluslararası Sosyal Araştırmalar Dergisi 4, 437 452.

Temel, A., Gündogdu, M.N., Gourgaud, A., Le Pennec, J.L., 1998. Ignimbrites of Cappadocia (Central Anatolia, Turkey): petrology and geochemistry. Journal of Volcanology and Geothermal Research 85, 447-471.

Theodossiou-Drandaki,I, R. Nakov, W.A.P. Wimbledon, A.Serjani, A. Neziraj, H. Hallaci, G. Sijaric, P. Begovic, T. Todorov, Pl. Tchoumatchenco, A. Diakantoni, Ch. Fassoulas, N. Kazanc1, F. Saroglu, A. Dogan, M. Dimitrijevic, D. Gavrilovic B. Krstic, D. Mijovic, 2004, IUGS Geosites project progress - a first attempt at a common framework list for south eastern European countries. In: M. Parkes, Ed., Natural and Cultural Landscapes- the geological 
foundation. Proceedings of a Conference 9-11 September 2002, Dublin Castle, Ireland, Royal Irish Academy, Dublin, pp. 81-90.

Toprak, S., 2013. Petrographical properties of a semi-precious coaly stone, Oltu stone, from eastern Turkey. International Journal of Coal Geology 120, 95-101.

Toprak, V., Savaşçın, Y., Güleç, N., Tankut, A. 1996. Structure of the Galatean volcanic province. International Geology Review 38, 747-758.

TR-ME (Republic of Turkey Ministry of Economy) 2012. Natural Stones. Broșür, $8 \mathrm{~s}$, Ankara.

TSE, 2012. Mermer ve Doğal Taş Sektörü. Standard Dergisi 606, 22-112.

USGS, 2012. Famous building stones of our nation's capital. Fact Sheet April 2012, 3044, 1-2. http://pubs.usgs.gov/gip/ stones

Uzun, A., Uzun, S., 2001. Taşhaneden aşhaneye; taş pilekiler. OGU Sosyal Bilimler Dergisi 2, 149-168.

Yılmaz, S. ve Çakır, Ü., 2007. Yuvaköy civarındaki Ankara karmaşı̆̆ının petrolojik özellikleri. Türkiye Jeoloji Bülteni 50, 109-129.
Yılmaz, Y., Güner, Y., Saroğlu, F., 1998. Geology of the Quaternary volcanic centres of the east Anatolia. Journal of Volcanology and Geothermal Research 85, 173-210.

Yılmaz, Y., Şaroğlu, F., Güner, Y., 1987. Initiation of the neomagmatism in East Anatolia. Tectonophysics 137, 177-199.

Zengin, Y., 1955. Oltu taşı yatakları. MTA Dergisi 18, 147-149.

\section{Makale Geliş Tarihi ： 22 Ekim 2013 \\ Kabul Tarihi $\quad$ : 18 Aralık 2013}

Received

: 22 October 2013

Accepted
: 18 December 2013 